Article

\title{
Assessment of the Antimicrobial Potentiality and Functionality of Lactobacillus plantarum Strains Isolated from the Conventional Inner Mongolian Fermented Cheese Against Foodborne Pathogens
}

\author{
Zafarullah Muhammad 1,*, Rabia Ramzan ${ }^{2}$, Amro Abdelazez ${ }^{3}$, Adnan Amjad ${ }^{4}$ (D), \\ Muhammad Afzaal ${ }^{5}{ }^{-}$, Shanshan Zhang ${ }^{1}$ and Siyi Pan ${ }^{1, *}$ \\ 1 Key Laboratory of Environment Correlative Dietology, Ministry of Education, \\ Huazhong Agricultural University, Wuhan 430070, China; shaunazss@163.com \\ 2 Food Biotechnology and Food Safety Laboratory, Huazhong Agricultural University, Wuhan 430070, China; \\ rabiaramzan@webmail.hzau.edu.cn \\ 3 Department of Dairy Microbiology, Animal Producrion Research Institute, \\ Agriculture Research Center Dokki, Giza 12618, Egypt; amorbiotic@yahoo.com \\ 4 Institute of Food Science and Nutrition, Bahauddin Zakariya University, Multan 60800, Pakistan; \\ adnanft01@gmail.com \\ 5 Department of Food Science, Nutrition and Home Economics, Government College University, \\ Faisalabad 54000, Pakistan; muhammadafzaal@gcuf.edu.pk \\ * Correspondence: zafmuhammad@mail.hzau.edu.cn (Z.M.); profdrpansiyi.hzau.edu@outlook.com (S.P.); \\ Tel.: +86-139-7126-1665 (Z.M.); +86-135-5402-9828 (S.P.)
}

Received: 17 April 2019; Accepted: 13 May 2019; Published: 21 May 2019

check for updates

\begin{abstract}
Lactobacillus plantarum are amongst the diversified lactic acid bacteria (LAB) species which are being utilized abundantly in the food industry. Numerous L. plantarum strains have been reported to produce several antimicrobial compounds. Diacetyl, hydrogen peroxide, organic acids, as well as bacteriocins can also be exemplified by a variable spectrum of actions. The current study was intended to conduct the screening and characterization of antimicrobial prospective of L. plantarum from traditional Inner Mongolian fermented hard cheese. Foodborne pathogens, Salmonella typhimurium, Escherichia coli O157:H7, Listeria monocytogenes, and Staphylococcus aureus, were examined by using the Oxford cup technique and the mixed culture inhibition assays. The resulting analyses disclosed that L. plantarum KLDS1.0344 indicated broad antimicrobial spectrum against all selected pathogens as compared to other LAB used in this study. Additionally, the decrement of the pathogen population was observed up to 3.47 logs in mixed culture inhibition assays. L. plantarum KLDS 1.0344 acid production was recorded up to $71.8 \pm 3.59^{\circ} \mathrm{D}$ in mixed culture while antimicrobial particles released in cell free supernatants demonstrated bacteriocin-like characteristics showing substantial pH stability (2.0-6.0), proteolytic enzyme reduced the antibacterial activity $(15.2 \pm 0.6 \mathrm{~mm}-20.4 \pm 0.8 \mathrm{~mm})$, heat stability $\left(20 \mathrm{~min}\right.$ at $120^{\circ} \mathrm{C}$ ) against selected pathogens. Moreover, the spectrum range of antimicrobial peptides after the partial purification was decreased as compared to the crude bacteriocin-like compound. The SDS-PAGE analysis showed the molecular weight range of partially purified bacteriocin from 12 to $45 \mathrm{kDa}$. After analyzing the obtained data from the current experimentation showed that the capability of L. plantarum KLDS 1.0344 to oppose the pathogen growth in vitro relies on the occurrence of organic acids along with bacteriocin-like compounds proving L. plantarum KLDS 1.0344 as a potentially appropriate candidate as an alternative bio-control agent against foodborne pathogens.
\end{abstract}

Keywords: Lactobacillus plantarum; foodborne pathogens; antimicrobial potency; antibacterial peptide; physico-chemical stability; conventional hard cheese 


\section{Introduction}

The progressive attention of the clients towards natural and healthy diet has actuated the food science research and industry to explore and present natural compounds to process and preserve food products and to mitigate the utilization of chemical additives as antimicrobials. A careful and systematic research to control the Food Borne Diseases (FBDs) is a multi-faceted task obliging talents in the areas of food microbiology and chemistry, food control, food safety, as well as, food management [1-3].

Presently, various lines of research have been or being tried to encounter "the chemical problem" by "the natural solution". Among these investigations, selection of the bacterial strains capable to develop compounds, which can be utilized as preservatives or antimicrobials, verified that the lactic acid bacteria (LAB) might be apposite microorganisms for such "natural solutions" [4-6].

Due to its technological and probiotic characteristics Lactobacillus plantarum is considered as the most important species of Lactobacilli $[7,8]$. The biosynthetical production of the bioactive peptides, enzyme systems, organic acids, exopolysaccharides, and vitamins are said to be one of the key mechanisms by which antioxidant, antimicrobial and probiotic activities are carried out [7]. The probiotic properties and antagonistic features of the L. plantarum strains could be the unique characteristics which enable them to be utilized as biocontrol agents against potentially dangerous microbes during processing and storage of the food and, it also elongates the shelf-life and safety of the fermented food products. The presence of these probiotic strains in fermented food systems can possibly contribute to the reduction of chemical compounds and can increase the health and wellbeing of the consumer [9]. The L. plantarum strains have been found to possess the best probiotic properties like acid and bile salt tolerance, the ability to adhere Caco-2 cells, the surface hydrophobicity properties, and significant hypochlesterolemic and antioxidant activities [10].

Various L. plantarum strains might have been identified to produce numerous antimicrobial agents against certain pathogenic microorganisms which are the main cause of food spoilage. This antimicrobial impact has frequently been attributed to the organic acid synthesis, like, lactic and phenyl lactic acids [11-14]. Conversely, the synthesis of bacteriocin-like or antimicrobial peptides has also been described to assert the antagonistic potentiality by the lactobacilli $[15,16]$. The hostility of certain bacteria and their extracellular substances present in cell free supernatants (CFS) provide useful prospects for food conservation [12,17]. Recently, due to having extensive ties with foods and the status of GRAS (generally recognized as safe) the LAB and their products have gained significant attention in the field of food processing and preservation [18]. As natural preservatives and ingredients for the starters to manufacture the probiotic functional foods, the LAB could be utilized to tackle the foodborne diseases. $[19,20]$. Hence, all this needs an obligatory selection of the lactobacilli strains and bifidobacteria with probiotic characteristics [21].

Isolation of L. plantarum strains have been carried out from different traditional cheese products, for instance several Iranian and Italian cheese varieties [22], Polish golka cheese [23], Greek Melichloro cheese [24], Turkish Karin Kaymak cheese [25], Serbian Zlatar cheese [26], Indian camel cheese [27], Brazilian ovine cheese [28], Tibetan Qula cheese [29], and West African soft cheese [30]. The key motive of the current assessment was to explore the antimicrobial potentials of L. plantarum spp., isolated from Hurood cheese, which is a conventional type of hard cheese. It contains $25 \%$ moisture content and it is traditionally manufactured and consumed in the Inner Mongolian region of China for hundreds of years and representing the natural antimicrobials against prominent foodborne pathogens [31]. About 121 strains of LAB have been isolated from Hurood cheese, amongst them seven isolates have been identified as L. plantarum and have been investigated for their probiotic potentials, including their adhering ability to Caco-2 cells, tolerance to acid and bile salt, in vitro cholesterol reducing capability, surface hydrophobicity, and antioxidant activities [7,10,32]. For the purpose, we screened out L. plantarum KLDS strains, 1.0317, 1.0318, 1.0344, 1.0386, 1.0628, 1.0985, 1.0986 from the customary fermented cheese in Inner Mongolia, against foodborne pathogens.

Pathogens used in our study were Salmonella spp., Listeria monocytogenes Staphylococcus aureus and E. coli O157:H7. Public health and quality of food products are greatly affected by the Salmonella 
typhimurium. It has been considered as the most common pathogen around the world causing foodborne illnesses [33]. For example only in China Salmonella species have been considered responsible for about $40 \%$ of bacteria related to food poisoning [34]. The majority of people infected with Salmonella typhimurium suffer from diarrhea, fever, abdominal cramps. Contaminated chicken, milk, cucumber, raw tuna, pork, beef, eggs and seafood are considered as the reservoir of Salmonella typhimurium and involved in the outbreaks of illnesses linked to these species $[35,36]$. Listeria monocytogenes also involved in several illnesses like abortion, gastrointestinal diseases and these diseases are related to foods supporting the proliferation of this bacteria. It may also cause meningoencephalitis with or without bacteremia and, more important, it causes intrauterine infection with high mortality [37,38]. Even the Listeria monocytogenes can survive in foods having water activity less than 0.85 . These foods are termed as LMFs or low moisture foods like dry fermented sausages, cereals, tree nuts, fermented cheeses and infant formula powders [23,39]. Staphylococcus aureus can cause scarlet fever, respiratory diseases and life-threatening toxic shock syndrome as this syndrome involves the infections in nervous system, hematologic, renal, muscular and gastrointestinal systems [40,41]. Moreover, Staphylococcus aureus involves skin infections like folliculitis, furuncle and carbuncles. These skin illnesses are rarely curable which leads to life-threatening septicemia [42]. Food poisoning with symptoms like vomiting, diarrhea, dehydration and nausea can also be caused by Staphylococcus aureus [43]. Contaminated water, uncooked or partially processed foods like, juices, sprouts, leafy greens, ground beef, peanut butter, soy-nut butter and milk based fermented and non-fermented products are a rich source of E. coli O157:H7 [37]. E. coli O157:H7 contamination aggravates life-threatening hemolytic-uremic syndrome [44] and hemorrhagic colitis [45].

We have tested several L. plantarum KLDS strains to assess their potential against these foodborne pathogens. We have also explored the antimicrobial spectrum of L. plantarum KLDS strains, selected and used in this study. We studied the chemical characteristics of the molecules probably explaining the perceived antimicrobial potential, as well as, its stability.

\section{Results}

\subsection{Antimicrobial Potentiality Screening by Oxford Cup Technique}

Antimicrobial potentiality of L. plantarum strains against the given pathogens (foodborne) was evaluated by the Oxford Cup Technique. Subsequent data is presented in Tables 1 and 2. L. plantarum (KLDS 1.0344) displayed most potent antimicrobial potential among all L. plantarum strains against the given pathogens. Specifically, the inhibition zone of $S$. aureus reached $15.8 \pm 0.1 \mathrm{~mm}$ and $13.8 \pm 0.0 \mathrm{~mm}$ by culture and CFS respectively. Whereas, the smallest inhibition zone was detected against L. monocytogenes by culture $(9.2 \pm 0.1 \mathrm{~mm})$ and CFS $(8.5 \pm 0.0 \mathrm{~mm})$. L. plantarum KLDS 1.0985 and its cell-free supernatants only displayed antimicrobial competency opposite to L. monocytogenes $(8.8 \pm 0.1 \mathrm{~mm}$ and $5.3 \pm 0.1 \mathrm{~mm}$ successively) and S.typhimurium $(4.9 \pm 0.2 \mathrm{~mm}$ and $3.0 \pm 0.1 \mathrm{~mm})$, but no considerable effect detected against $S$. aureus and E. coli (Table 2).

L. plantarum KLDS $(1.0318,1.0317,1.0344,1.0386,1.0985,1.0986)$ altogether displayed antimicrobial ability counter to L. monocytogenes, but L. plantarum KLDS 1.0628 demonstrated antimicrobial activity $(p<0.05)$ against $S$. aureus. Moreover, their cultures produced larger inhibition zones compared to CFSs. The above-given results also indicate the part of antimicrobial potency of L. plantarum KLDS 1.0344 could be from microbes themselves. Therefore, in accordance with the obtained results from the screening of antimicrobial potentiality, L. plantarum KLDS 1.0344 was suggested to be the best efficient to inhibit pathogens (foodborne) and were utilized for further experimentations. 
Table 1. Antimicrobial potential of L. plantarum KLDS 1.0317, 1.0318, 1.0344, 1.0386, 1.0628, 1.0985, 1.0986 cultures' by measuring inhibition zones $(\mathrm{mm})$ against indicator pathogens.

\begin{tabular}{|c|c|c|c|c|c|c|c|}
\hline & $\begin{array}{l}\text { KLDS } \\
1.0317\end{array}$ & $\begin{array}{l}\text { KLDS } \\
1.0318\end{array}$ & KLDS 1.0344 & $\begin{array}{l}\text { KLDS } \\
1.0386\end{array}$ & $\begin{array}{l}\text { KLDS } \\
1.0628\end{array}$ & $\begin{array}{l}\text { KLDS } \\
1.0985\end{array}$ & $\begin{array}{l}\text { KLDS } \\
1.0986\end{array}$ \\
\hline $\mathrm{pH}$ & $4.6 \pm 0.0^{E}$ & $4.9 \pm 0.0^{C}$ & $3.4 \pm 0.1^{\mathrm{G}}$ & $5.5 \pm 0.1^{A}$ & $5.3 \pm 0.0^{B}$ & $4.7 \pm 0.0^{\mathrm{D}}$ & $4.4 \pm 0.0^{F}$ \\
\hline Pathogens & Culture & Culture & Culture & Culture & Culture & Culture & Culture \\
\hline L. monocytogenes & $11.2 \pm 0.1 \mathrm{aA}$ & $5.6 \pm 0.1^{\mathrm{abE}}$ & $9.2 \pm 0.1^{b B}$ & $7.9 \pm 0.0^{\mathrm{aD}}$ & - & $8.8 \pm 0.1^{\mathrm{aC}}$ & $9.3 \pm 0.1^{\mathrm{aB}}$ \\
\hline S. aureus & - & $6.9 \pm 0.2^{\mathrm{aC}}$ & $15.8 \pm 0.1^{\mathrm{aA}}$ & - & $5.7 \pm 0.0^{\mathrm{aB}}$ & - & - \\
\hline S. typhimurium & $7.8 \pm 0.0^{\mathrm{bB}}$ & - & $14.2 \pm 0.0^{\mathrm{aA}}$ & - & - & $4.9 \pm 0.2^{b C}$ & - \\
\hline \multirow[t]{3}{*}{ E. coli $\mathrm{O} 157: \mathrm{H7}$} & - & - & $12.7 \pm 0.0^{\mathrm{abA}}$ & - & - & - & - \\
\hline & KLDS & KLDS & \multirow{2}{*}{ KLDS 1.0344} & KLDS & KLDS & KLDS & KLDS \\
\hline & 1.0317 & 1.0318 & & 1.0386 & 1.0628 & 1.0985 & 1.0986 \\
\hline $\mathrm{pH}$ & $5.6 \pm 0.1^{\mathrm{A}}$ & $4.8 \pm 0.0^{\mathrm{D}}$ & $3.3 \pm 0.1^{\mathrm{G}}$ & $5.4 \pm 0.0^{B}$ & $5.3 \pm 0.0^{C}$ & $4.7 \pm 0.0^{\mathrm{E}}$ & $4.3 \pm 0.1^{F}$ \\
\hline Pathogens & CFS & CFS & CFS & CFS & CFS & CFS & CFS \\
\hline L. monocytogenes & $8.4 \pm 0.2^{\mathrm{aA}}$ & $2.4 \pm 0.0^{\mathrm{cE}}$ & $8.5 \pm 0.0^{b A}$ & $4.6 \pm 0.1^{\mathrm{bD}}$ & - & $5.3 \pm 0.1^{\mathrm{aC}}$ & $6.3 \pm 0.0^{\mathrm{aB}}$ \\
\hline S. aureus & - & $3.7 \pm 0.0 \mathrm{aC}$ & $13.8 \pm 0.0 \mathrm{aA}$ & - & $3.0 \pm 0.0^{\mathrm{bB}}$ & - & - \\
\hline S. typhimurium & $4.9 \pm 0.0^{\mathrm{bB}}$ & - & $12.4 \pm 0.1^{\mathrm{aA}}$ & - & - & $3.0 \pm 0.9^{b C}$ & - \\
\hline E. coli $\mathrm{O} 157: \mathrm{H7}$ & - & - & $10.4 \pm 0.1 \mathrm{abA}$ & - & - & - & - \\
\hline
\end{tabular}

Table 2. Spectrum of antimicrobial activity of culture of L. plantarum KLDS 1.0344 and its CFS by quantifying inhibition zones.

\begin{tabular}{lcccc}
\hline \multicolumn{1}{c}{ Indicator Bacterium } & Medium & Temperature & $\begin{array}{c}\text { Sensitivity } \\
\text { by Culture }\end{array}$ & Sensitivity by CFS \\
\hline $\mathrm{pH}$ & & & $3.23 \pm 0.06$ & $3.19 \pm 0.08$ \\
Lactobacillus paracasei KLDS1.0201 & mMRS & $37^{\circ} \mathrm{C}$ & + & + \\
Lactobacillus plantarum KLDS 1.0628 & mMRS & $37^{\circ} \mathrm{C}$ & + & + \\
Lactobacillus helveticus KLDS 1.9202 & mMRS & $37^{\circ} \mathrm{C}$ & + & + \\
Lactobacillus helveticus KLDS 1.9204 & mMRS & $37^{\circ} \mathrm{C}$ & + & + \\
Lactococcus lactis KLDS 4.0325 & M17 & $37^{\circ} \mathrm{C}$ & + & + \\
Sterptococcus thermophilus KLDS 3.0207 & M17 & $37^{\circ} \mathrm{C}$ & - & ++ \\
Escherichia coli ATCC 43889 & BHI & $37^{\circ} \mathrm{C}$ & +++ & +++ \\
Salmonella typhimurium ATCC 14028 & BHI & $37^{\circ} \mathrm{C}$ & +++ & +++ \\
Staphylococcus aureus ATCC 25923 & BHI & $37^{\circ} \mathrm{C}$ & +++ & ++ \\
Listeria monocytogenes ATCC 19115 & BHI & $37^{\circ} \mathrm{C}$ & ++ & - \\
Lactobacillus plantarum KLDS 1.0986 & mMRS & $37^{\circ} \mathrm{C}$ & - & + \\
\hline
\end{tabular}

Inhibition zone measurements (mm): No inhibition (-), 1 to $5 \mathrm{~mm} \mathrm{(+),} 5$ to $10 \mathrm{~mm}(++)$, bigger than $10 \mathrm{~mm}(+++)$.

\subsection{Determination of Inhibitory Substances of L. plantarum KLDS 1.0344 and Evaluate the Effect of Protease Enzymes on Their Activity}

The technological applicability of LAB characteristically grounded on the study of acidifying capability. In pure form, L. plantarum KLDS 1.0344 produced the highest levels of acidity $50.8 \pm 2.94{ }^{\circ} \mathrm{D}$ in $44 \mathrm{~h}$. In the mixed culture of L. plantarum with S. typhimurium, L. monocytogenes, S. aureus and E. coli, a high acidity $\left(71.8 \pm 3.59^{\circ} \mathrm{D}\right)$ was witnessed at $44 \mathrm{~h}$ (significant $\left.p<0.05\right)$. Kinetics of the $\mathrm{pH}$ progress (Figure 1) exhibited that L. plantarum reduced $\mathrm{pH}$ up to $4.7 \pm 0.02 \mathrm{in} 44 \mathrm{~h}$, while, in the mixed culture of L. plantarum and S. typhimurium, L. monocytogenes, S. aureus and E. coli was $4.3 \pm 0.01$. Insofar as, an antibacterial behavior of bacteriocin-like composite from L. plantarum KLDS 1.0344 for all selected pathogens was significantly declined after treating with several different proteolytic enzymes such as, pepsin treated with $12.7 \pm 0.5 \mathrm{~mm}$ for L. monocytogenes, $18.5 \pm 0.8 \mathrm{~mm}$ for S. aureus, $16.3 \pm 0.7 \mathrm{~mm}$ for S. typhimurium, and $15.6 \pm 0.6 \mathrm{~mm}$ for E. coli., From the results it was confirmed that the minimum inhibition zone was observed in bromelain enzyme case, $12.5 \pm 0.5 \mathrm{~mm}$ for L. monocytogenes, $18.2 \pm 0.7 \mathrm{~mm}$ for $S$. aureus, $16.0 \pm 0.6 \mathrm{~mm}$ for $S$. typhimurium, and $15.3 \pm 0.6 \mathrm{~mm}$ for E. coli. While the lowest decrease in inhibition zones were observed for protease treatment (Table 3). 
With every proteolytic enzyme treatment the antimicrobial activity clearly decreased, which exhibited that the antimicrobial compounds having a protein nature.

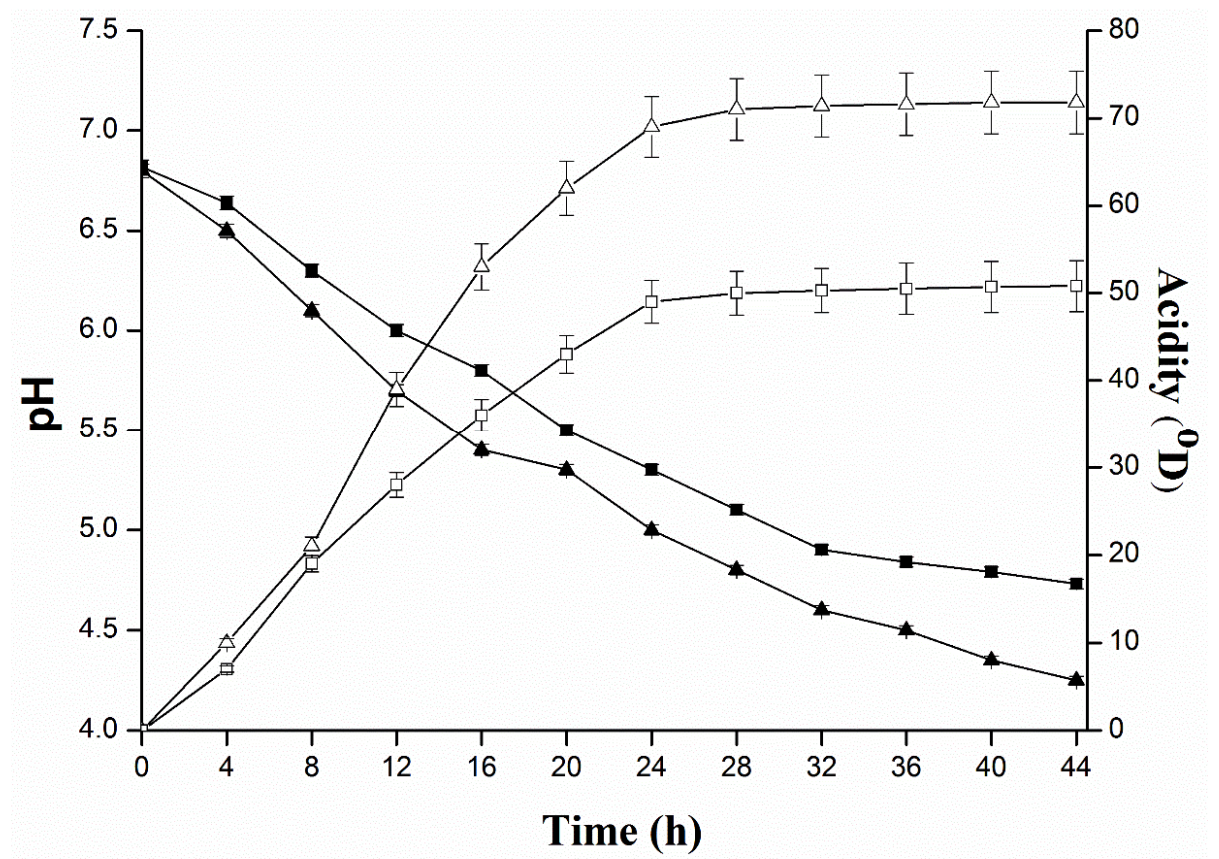

Figure 1. Evaluation of acidity ( $\square$ with solid line) and $\mathrm{pH}$ ( $\square$ with solid line) in pure culture and mixed culture of L. plantarum KLDS 1.0344, as well as acidity ( $\triangle$ with solid line and $\mathrm{pH}$ ( $\mathbf{\Delta}$ with solid line) in mixed cultures of L. monocytogenes ATCC 19115, S. typhimurium ATCC 14028, E. coli O157:H7 ATCC 43889, S. aureus ATCC 25923.

Table 3. The effect of proteolytic enzymes on the antibacterial action of the antibacterial peptide from $L$. plantarum KLDS 1.0344 inhibiting the L. monocytogenes ATCC 19115, S. typhimurium ATCC 14028, E. coli O157:H7 ATCC 43889, S. aureus ATCC 25923 by measured inhibition zone diameters (mm).

\begin{tabular}{ccccc}
\hline Enzyme & L. monocytogenes & S. aureus & S. typhimurium & E. coli O157:H7 \\
\hline Control & $15.2 \pm 0.6^{\mathrm{a}}$ & $21.7 \pm 0.9^{\mathrm{a}}$ & $18.3 \pm 0.7^{\mathrm{a}}$ & $17.8 \pm 0.7^{\mathrm{a}}$ \\
Pepsin & $12.7 \pm 0.5^{\mathrm{e}}$ & $18.5 \pm 0.8^{\mathrm{d}}$ & $16.3 \pm 0.7^{\mathrm{d}}$ & $15.6 \pm 0.6^{\mathrm{d}}$ \\
Protease & $14.5 \pm 0.5^{\mathrm{b}}$ & $20.4 \pm 0.8^{\mathrm{b}}$ & $17.9 \pm 0.7^{\mathrm{ab}}$ & $17.2 \pm 0.7^{\mathrm{b}}$ \\
Pronase & $13.3 \pm 0.5^{\mathrm{de}}$ & $18.7 \pm 0.8^{\mathrm{cd}}$ & $16.8 \pm 0.6^{\mathrm{cd}}$ & $16.2^{\mathrm{d}} \pm 0.6^{\mathrm{d}}$ \\
Bromelain & $12.5^{\mathrm{a}} \pm 0.5^{\mathrm{e}}$ & $18.2 \pm 0.7^{\mathrm{e}}$ & $16.0 \pm 0.6^{\mathrm{e}}$ & $15.3 \pm 0.6^{\mathrm{e}}$ \\
Ficin & $14.0 \pm 0.6^{\mathrm{c}}$ & $19.8 \pm 0.8^{\mathrm{bc}}$ & $17.5 \pm 0.7^{\mathrm{b}}$ & $16.7^{\mathrm{b}} \pm 0.7^{\mathrm{bc}}$ \\
$\alpha$-Chymotrypsin & $13.5 \pm 0.6^{\mathrm{d}}$ & $19.3 \pm 0.8^{\mathrm{c}}$ & $17.0 \pm 0.6^{\mathrm{c}}$ & $16.4 \pm 0.7^{\mathrm{c}}$ \\
\hline
\end{tabular}

Data is shown as mean \pm SD (standard deviation); The values presented in a column with different superscripts are significantly different $(p<0.05)$.

\subsection{Partial Purification, Molecular Weight, Thermal and $p H$ Stability of Bacteriocin}

In present research work, bacteriocins-like compounds, produced by L. plantarum (KLDS 1.0344), were partly cleaned by precipitation and dialysis of ammonium sulfate. Antimicrobial potential of bacteriocin was assessed against four pathogens, such as S. aureus, S. typhimurium, E. coli and L. monocytogenes. Inhibition zones of four pathogens were ominously dissimilar from each other after different treatments. Bacteriocin produced by L. plantarum KLDS 1.0344 after partial purification displayed ultimate antibacterial activity $(16.0 \pm 0.65-21.4 \pm 0.83 \mathrm{~mm})$ against the contestant pathogens as compared to the crude form (significantly $p<0.05$ ) (Figure 2). The obtained partially purified bacteriocin from L. plantarum KLDS 1.0344 was treated at different levels of $\mathrm{pH}$ to assess its antibacterial potentiality against pathogens (Table 4). The antibacterial potentiality of peptides contrary to all pathogens was lessened with augmented $\mathrm{pH}$ values. No antibacterial activity was observed beyond 
a $\mathrm{pH}$ of 6.0. Hence, the $\mathrm{pH}$ range of antibacterial activities of obtained bacteriocin from L. plantarum KLDS1.0344 was $\mathrm{pH} 2-6$. Table 5 also demonstrates that the thermal stability of bacteriocin resembling compounds were successively steady after subsequent treatments at $120{ }^{\circ} \mathrm{C}$ for 20 min retained inhibition activity of bacteriocin-like L. plantarum KLDS 1.0344 against pathogens L. monocytogenes $(85.0 \pm 0.7 \%)$, S. aureus $(86.5 \pm 0.3 \%)$, S. typhimurium $(83.0 \pm 0.0 \%)$, E. coli $\mathrm{O} 157: \mathrm{H} 7(81.0 \pm 0.2 \%)$. According to the SDS-PAGE analysis, bacteriocins-like are small polypeptides with a molecular weight in the range of 12,35 and $45 \mathrm{kDa}$ (Figure 3).

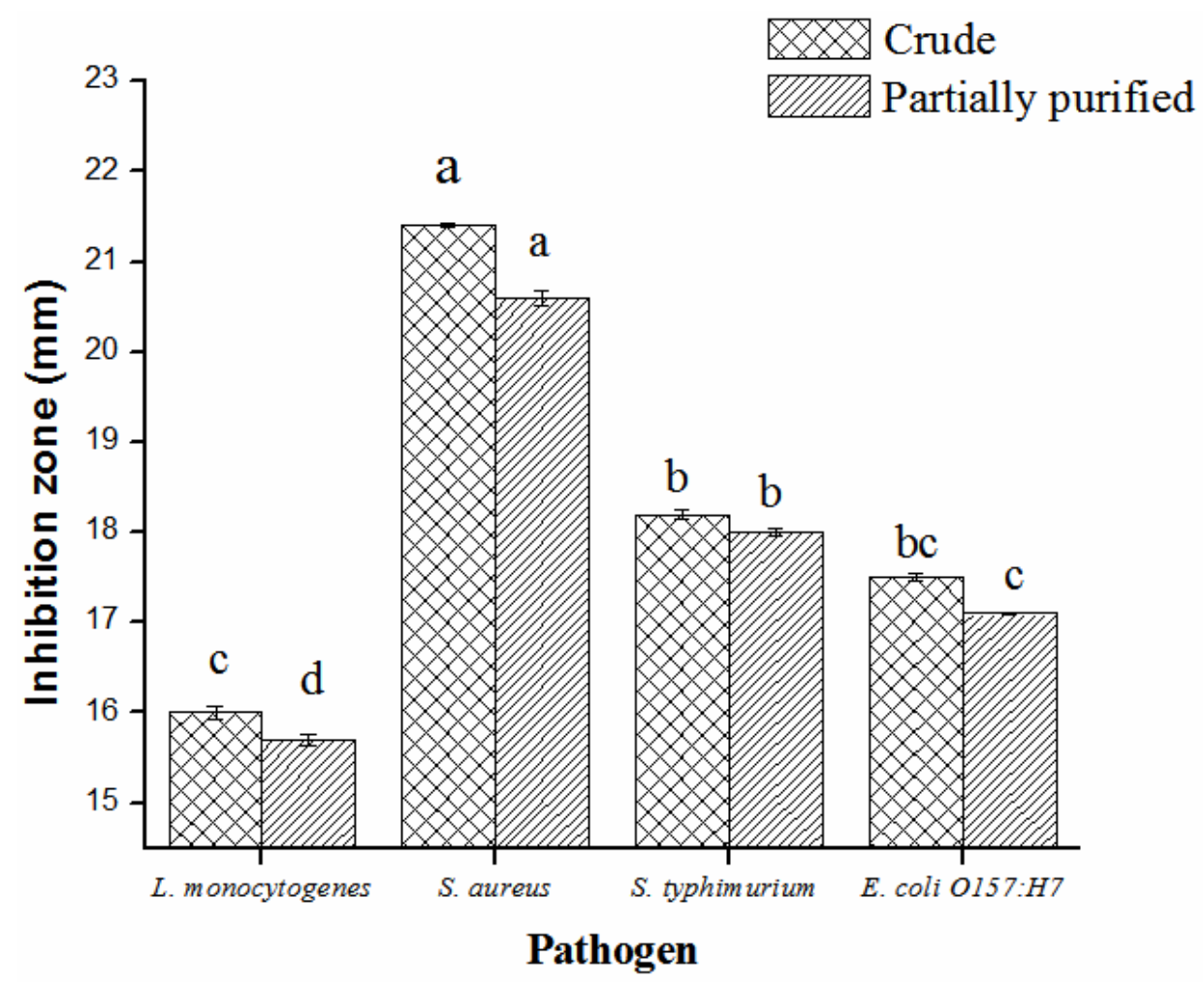

Figure 2. The antibacterial activities of the crude and partially purified bacteriocin isolated from $L$. plantarum KLDS 1.0344 against pathogens L. monocytogenes, S. typhimurium, E. coli, S. aureus measured by inhibition zone diameters. Bars signify the means of triplicate \pm SD.

Table 4. Effect of $\mathrm{pH}$ on the antibacterial activity of bacteriocins from L. plantarum KLDS 1.0344 against Listeria monocytogenes ATCC 19115, Salmonella typhimurium ATCC 14028, Escherichia coli O157:H7 ATCC 43889, Staphylococcus aureus ATCC 25923.

\begin{tabular}{ccccc}
\hline $\mathrm{pH}$ & L. monocytogenes & S. aureus & S. typhimurium & E. coli O157:H7 \\
\hline 2 & $100.0 \pm 0.0^{\mathrm{a}}$ & $100.0^{\mathrm{a}} \pm 0.0^{\mathrm{a}}$ & $100.0 \pm 0.0^{\mathrm{a}}$ & $100.0 \pm 0.0^{\mathrm{a}}$ \\
3 & $82.3^{\mathrm{b}} \pm 0.3^{\mathrm{b}}$ & $78.1 \pm 0.2^{\mathrm{b}}$ & $73.2^{\mathrm{b}} \pm 0.3^{\mathrm{b}}$ & $71.4 \pm 0.2^{\mathrm{b}}$ \\
4 & $65.4 \pm 0.2^{\mathrm{d}}$ & $60.0^{\mathrm{a}} \pm 0.2^{\mathrm{c}}$ & $56.4 \pm 0.2^{\mathrm{c}}$ & $54.0 \pm 0.2^{\mathrm{c}}$ \\
5 & $50.0 \pm 0.2^{\mathrm{e}}$ & $42.4 \pm 0.1^{\mathrm{d}}$ & $39.1 \pm 0.1^{\mathrm{d}}$ & $33.0 \pm 0.1^{\mathrm{d}}$ \\
6 & $29.2 \pm 0.1^{\mathrm{f}}$ & $20.2 \pm 0.1^{\mathrm{f}}$ & $16.0 \pm 0.0^{\mathrm{f}}$ & $15.2 \pm 0.0^{\mathrm{f}}$ \\
7 & $0.0 \pm 0.0^{\mathrm{g}}$ & $0.0 \pm 0.0^{\mathrm{g}}$ & $0.0 \pm 0.0^{\mathrm{g}}$ & $0.0 \pm 0.0^{\mathrm{g}}$ \\
8 & $0.0 \pm 0.0^{\mathrm{g}}$ & $0.0 \pm 0.0^{\mathrm{g}}$ & $0.0 \pm 0.0^{\mathrm{g}}$ & $0.0 \pm 0.0^{\mathrm{g}}$ \\
\hline
\end{tabular}

Inhibition activity $(\%)=\left[(\text { diameter of inhibition zone })^{2}-(10 \mathrm{~mm})^{2} /(\text { diameter of maximum inhibition zone })^{2}-\right.$ $\left.(10 \mathrm{~mm})^{2}\right] \times 100 \%$. The data values are expressed as the mean \pm standard deviation $(n=3)$. Values in a column with different superscript letters are significantly different $(p<0.05)$. 
Table 5. Effect of heat on the antibacterial action of bacteriocins from L. plantarum KLDS 1.0344 encountering L. monocytogenes ATCC 19115, S. typhimurium ATCC 14028, E. coli O157:H7 ATCC 43889, S. aureus ATCC 25923. All results are presented in inhibition activity (\%).

\begin{tabular}{ccccc}
\hline Temperature/Time & L. monocytogenes & S. aureus & S. typhimurium & E. coli O157:H7 \\
\hline $80 / 20$ & $100.0 \pm 0.0^{\mathrm{a}}$ & $100.0 \pm 0.0^{\mathrm{a}}$ & $100.0 \pm 0.0^{\mathrm{a}}$ & $100.0 \pm 0.0^{\mathrm{a}}$ \\
$80 / 30$ & $100.0 \pm 0.0^{\mathrm{a}}$ & $100.0 \pm 0.0^{\mathrm{a}}$ & $100.0 \pm 0.0^{\mathrm{a}}$ & $100.0 \pm 0.0^{\mathrm{a}}$ \\
$80 / 40$ & $100.0 \pm 0.0^{\mathrm{a}}$ & $100.0 \pm 0.0^{\mathrm{a}}$ & $100.0 \pm 0.0^{\mathrm{a}}$ & $100.0 \pm 0.0^{\mathrm{a}}$ \\
$100 / 20$ & $100.0 \pm 0.0^{\mathrm{a}}$ & $100.0 \pm 0.0^{\mathrm{a}}$ & $100.0 \pm 0.0^{\mathrm{a}}$ & $100.0 \pm 0.0^{\mathrm{a}}$ \\
$100 / 30$ & $100.0 \pm 0.0^{\mathrm{a}}$ & $100.0 \pm 0.0^{\mathrm{a}}$ & $100.0 \pm 0.0^{\mathrm{a}}$ & $100.0_{0.0^{\mathrm{a}}}$ \\
$100 / 40$ & $100.0 \pm 0.0^{\mathrm{a}}$ & $100.0 \pm 0.0^{\mathrm{a}}$ & $100.0 \pm 0.0^{\mathrm{a}}$ & $100.0_{0.0^{\mathrm{a}}}$ \\
$120 / 20$ & $85.0 \pm 0.7^{\mathrm{b}}$ & $86.5 \pm 0.3^{\mathrm{b}}$ & $83.0 \pm 0.1^{\mathrm{b}}$ & $81.0 \pm 0.2^{\mathrm{b}}$ \\
$120 / 30$ & $74.3 \pm 0.4^{\mathrm{c}}$ & $78.0 \pm 0.2^{\mathrm{c}}$ & $71.5 \pm 0.1^{\mathrm{c}}$ & $69.0 \pm 0.0^{\mathrm{c}}$ \\
$120 / 40$ & $61.2 \pm 0.1^{\mathrm{d}}$ & $54.5 \pm 0.1^{\mathrm{d}}$ & $47.0 \pm 0.3^{\mathrm{d}}$ & $40.5 \pm 0.0^{\mathrm{d}}$ \\
\hline
\end{tabular}

Inhibition activity $(\%)=\left[(\text { diameter of inhibition zone })^{2}-(10 \mathrm{~mm})^{2} /(\text { diameter of maximum inhibition zone })^{2}-\right.$ $\left.(10 \mathrm{~mm})^{2}\right] \times 100 \%$. The data values are expressed as the mean \pm SD $(n=3)$. Values in a column with different superscripts are significantly different $(p<0.05)$.

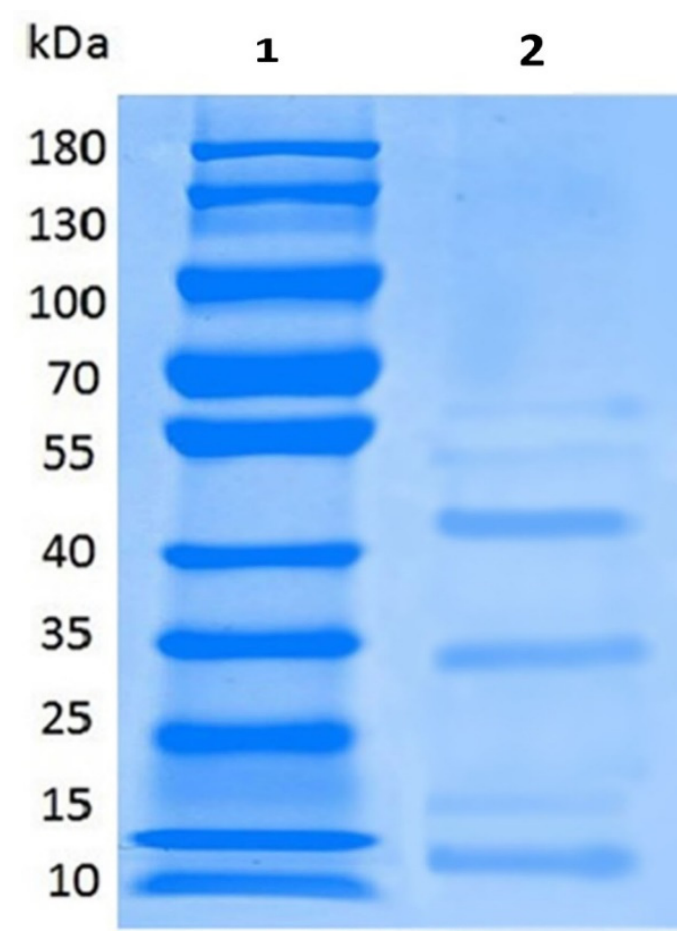

Figure 3. A bacteriocin protein profile of SDS-PAGE of L. plantarum 1.0344, Lane 1: Molecular weight marker; Lane 2: Partially purified bacteriocin protein produced by L. plantarum 1.0344.

\subsection{Mixed Culture Inhibition Assay}

While exploring the antimicrobial effects of L. plantarum KLDS 1.0344 on E. coli, S. typhimurium, S. aureus and L. monocytogenes, we executed the mixed culture inhibition assay and the results are shown in Figure 4. Observations revealed that in all groups $\mathrm{pH}$ of the cultures displayed evidential $(p<0.05)$ decline. Viable counts of L. plantarum with all pathogens in monoculture co-cultured and diffusion chamber groups are noticeably different $(p<0.05)$ among the groups with an increasing trend. Figure 4A-D) exhibits the growth of L. plantarum KLDS 1.0344 (maximum population of $8.8 \log$ CFU per $\mathrm{mL}$ ) was comparable to that attained in monoculture. 


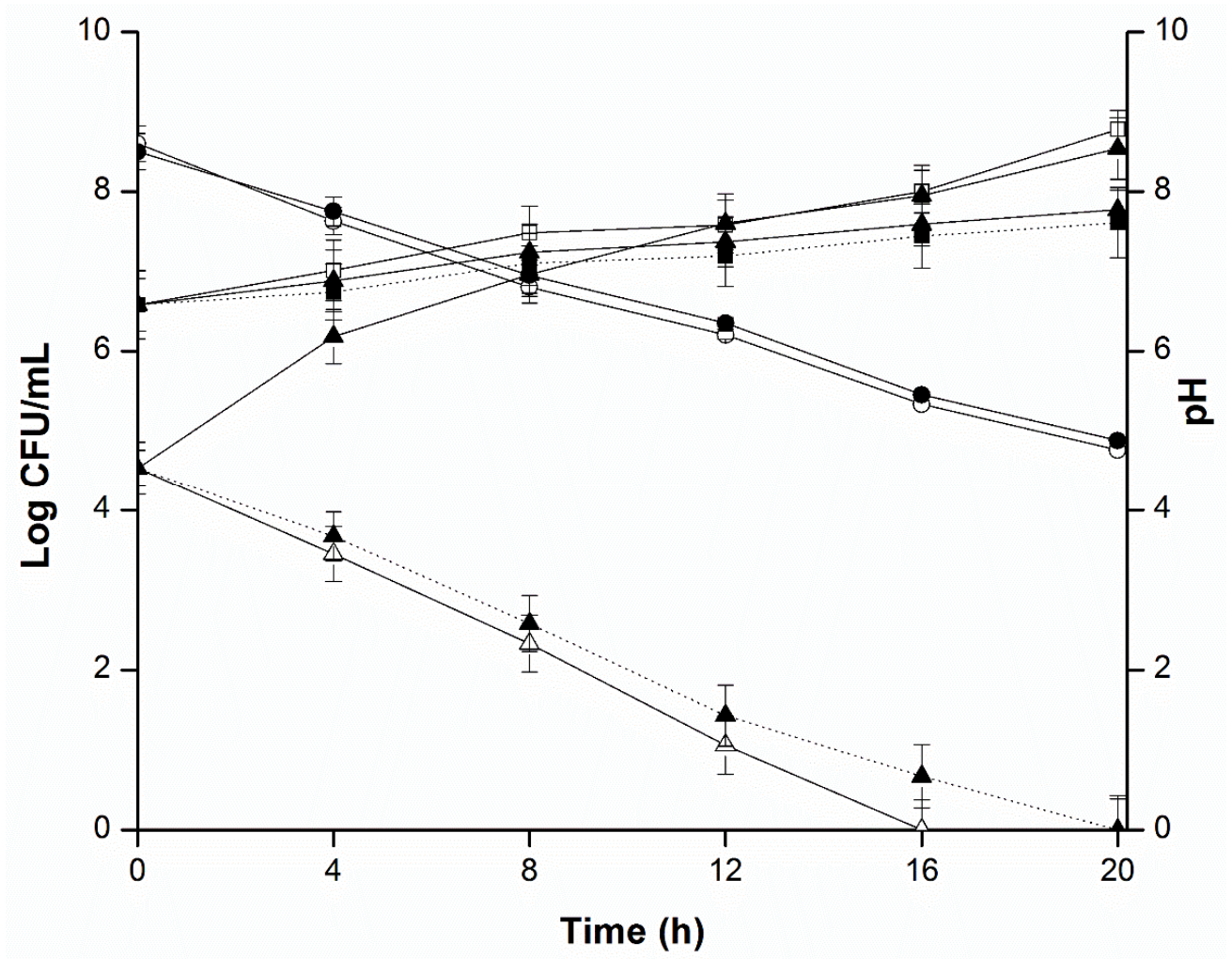

(A)

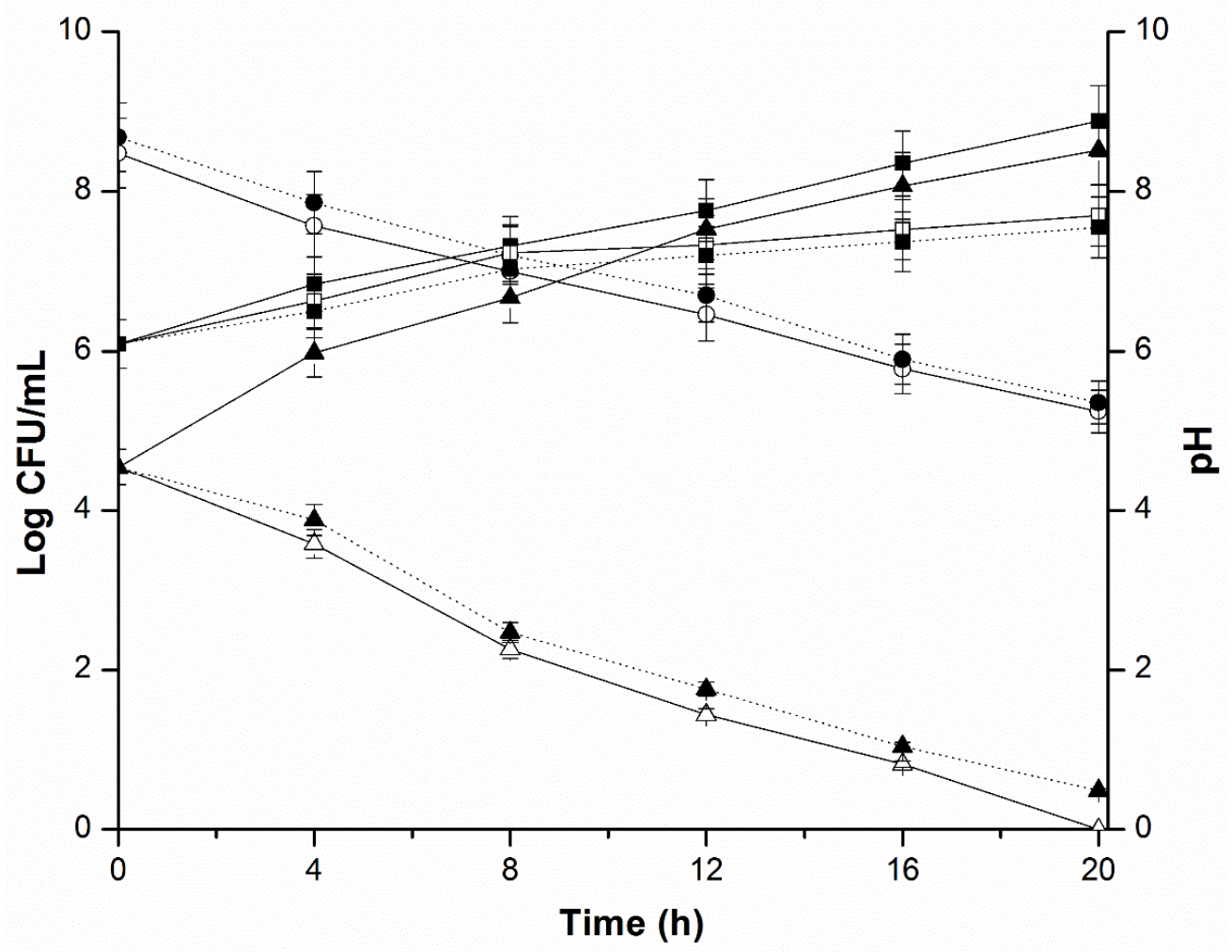

(B)

Figure 4. Cont. 


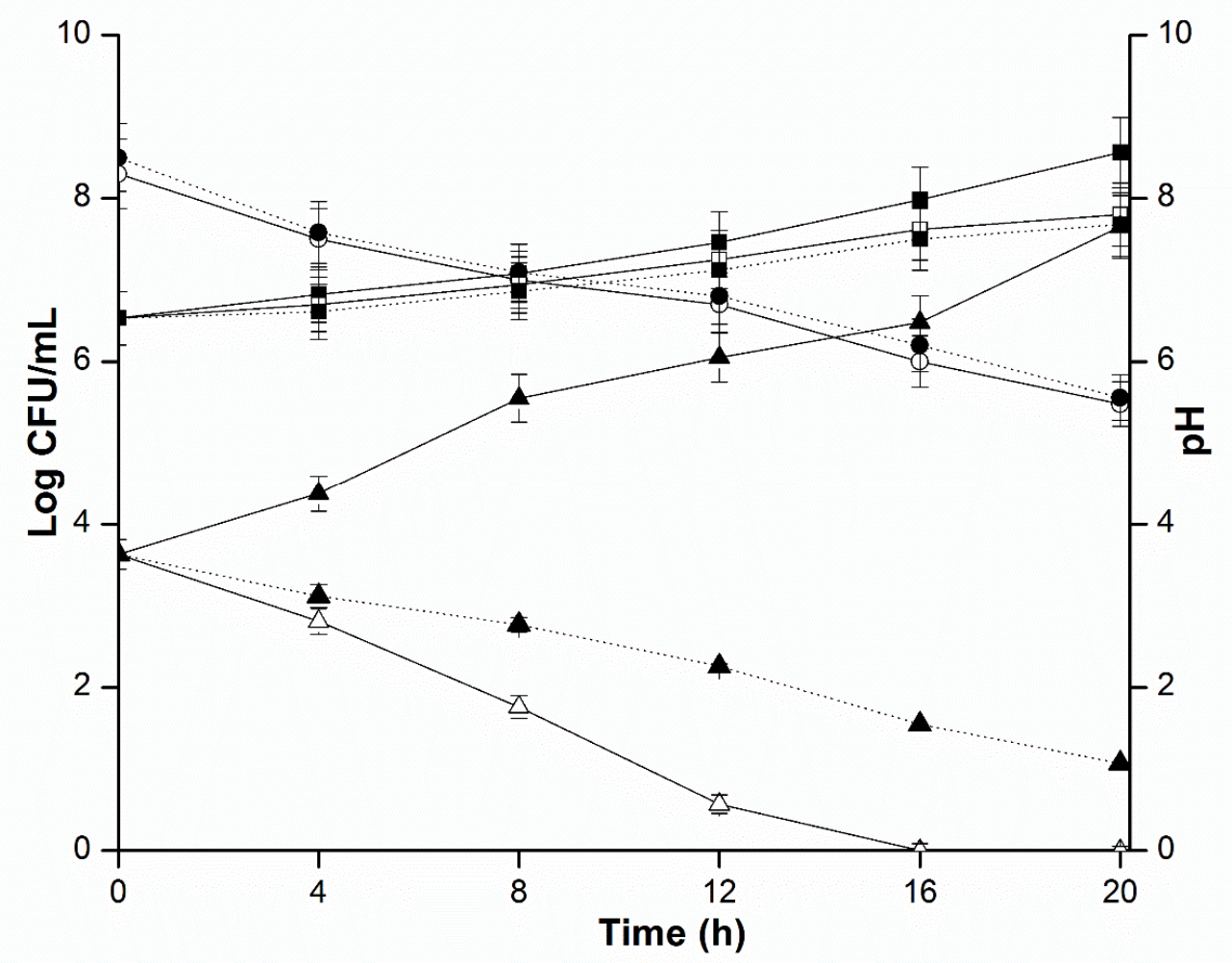

(C)

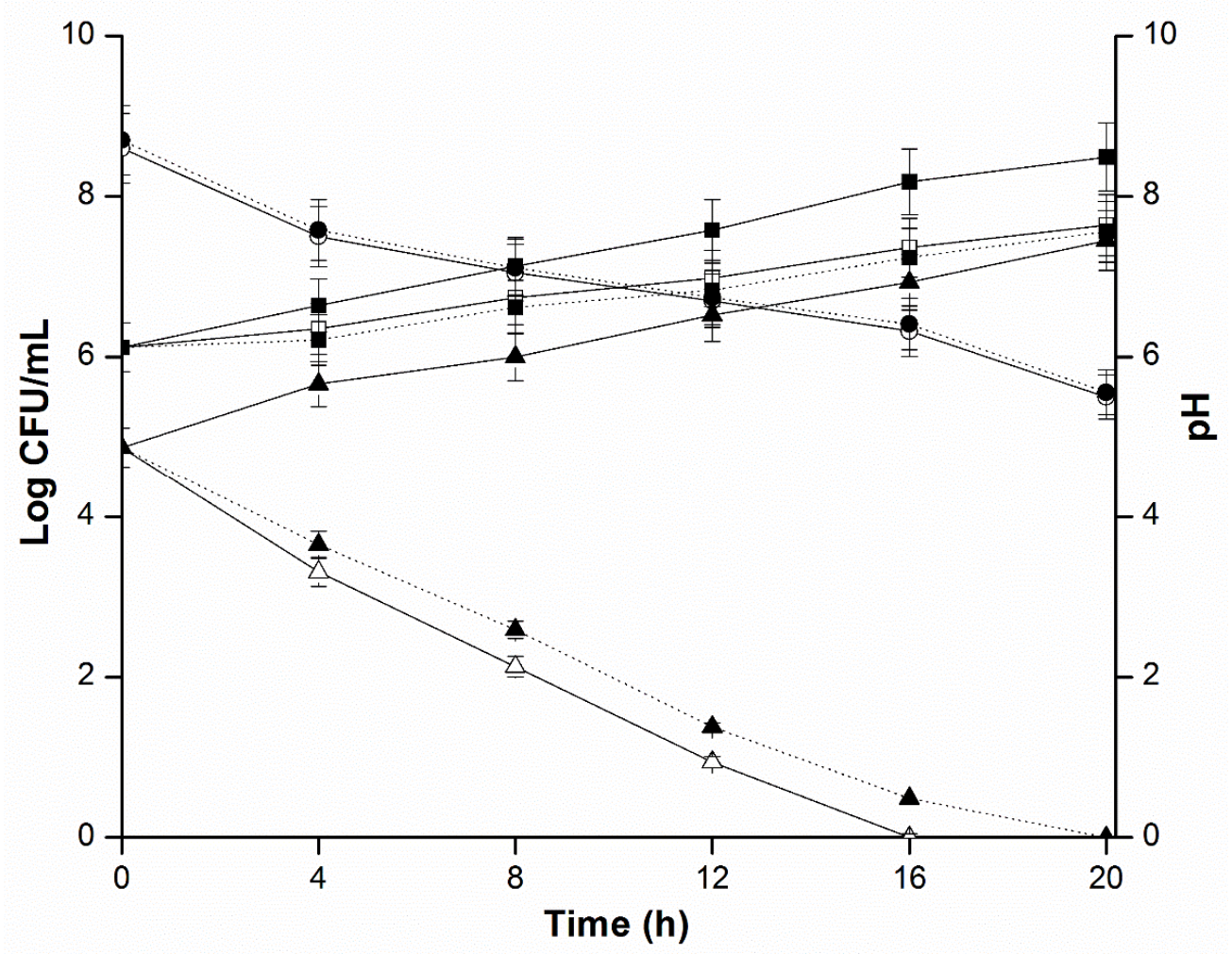

(D)

Figure 4. (A) Progression of L. plantarum KLDS 1.0344, pathogens and shift of $\mathrm{pH}$ in contact co-culture experiment ( $\mathbf{\Delta}$ with flecked line, $\mathbf{\Delta}$ with solid line and $\Delta$ with solid line) represents quantity of viable pathogens containing S. aureus in monoculture group, co-cultured with L. plantarum KLDS 1.0344 and 
diffusion chamber groups correspondingly; ( with flecked line, $\square$ with solid line, and $\square$ with solid line) represents viable counts of co-cultured with pathogens group, L. plantarum KLDS 1.0344 in monoculture group and diffusion chamber group correspondingly; ( $\bigcirc$ with solid line and $\bullet$ with flecked line) represents $\mathrm{pH}$ of cultures in corresponding diffusion chamber and co-culture groups. (B) Progression of L. plantarum KLDS 1.0344, pathogens and shift of $\mathrm{pH}$ in contact co-culture experiment ( $\mathbf{\Lambda}$ with flecked line, $\Delta$ with solid line and $\Delta$ with solid line) represents quantity of viable pathogens containing $E$. coli O157:H7 in monoculture group, co-cultured with L. plantarum KLDS 1.0344 and diffusion chamber groups correspondingly; ( $\mathbf{\square}$ with flecked line, $\mathbf{\square}$ with solid line, and $\square$ with solid line) represents viable counts of co-cultured with pathogens group, L. plantarum KLDS 1.0344 in monoculture group and diffusion chamber group correspondingly; ( $\bigcirc$ with solid line and $\bullet$ with flecked line) represents $\mathrm{pH}$ of cultures in corresponding diffusion chamber and co-culture groups. (C) Progression of L. plantarum KLDS 1.0344, pathogens and shift of $\mathrm{pH}$ in contact co-culture experiment ( $\mathbf{\Delta}$ with flecked line, $\mathbf{\Delta}$ with solid line and $\Delta$ with solid line) represents quantity of viable pathogens containing $S$. typhimurium in monoculture group, co-cultured with L. plantarum KLDS 1.0344 and diffusion chamber groups correspondingly; ( $\mathbf{\square}$ with flecked line, $\mathbf{\square}$ with solid line, and $\square$ with solid line) represents viable counts of co-cultured with pathogens group, L. plantarum KLDS 1.0344 in monoculture group and diffusion chamber group correspondingly; ( $\bigcirc$ with solid line and - with flecked line) represents $\mathrm{pH}$ of cultures in corresponding diffusion chamber and co-culture groups. (D) Progression of L. plantarum KLDS 1.0344, pathogens and shift of $\mathrm{pH}$ in contact co-culture experiment ( $\boldsymbol{\Delta}$ with flecked line, $\mathbf{\Delta}$ with solid line and $\Delta$ with solid line) represents quantity of viable pathogens containing L. monocytogenes in monoculture group, co-cultured with L. plantarum KLDS 1.0344 and diffusion chamber groups correspondingly; ( with flecked line, $\mathbf{\square}$ with solid line, and $\square$ with solid line) represents viable counts of co-cultured with pathogens group, L. plantarum KLDS 1.0344 in monoculture group and diffusion chamber group correspondingly; ( $\bigcirc$ with solid line and $\bullet$ with flecked line) represents $\mathrm{pH}$ of cultures in corresponding diffusion chamber and co-culture groups.

Whereas, decline in the number of viable cells of the E. coli O157:H7, S. typhimurium, L. monocytogenes and, S. aureus (ATCC 19115) in diffusion chamber, as well as in co-cultured groups ranged from 2.56 to 3.47 logs, were highly significantly different from the counts of all pathogen in monoculture $(p<0.001)$. Viable counts of pathogens decreased in diffusion chamber and co-cultured groups, whilst increased in monoculture group. Besides, the viable count of pathogens in the diffusion chamber group reduced up to 0 logs per $\mathrm{ml}$ after $20 \mathrm{~h}$, while flatly declined to in co-culture group. Withal, in three groups the $\mathrm{pH}$ values of BHI were not significantly dissimilar $(p>0.05)$. Furthermore, the results from diffusion chamber culture and co-culture of L. plantarum KLDS 1.0344 with E. coli, S. typhimurium, S. aureus and L. monocytogenes, signifying the participation of a secreted inhibitory molecule from L. plantarum KLDS 1.0344, as well as, bacteria itself. However, only the antibacterial substances secreted by L. plantarum KLDS 1.0344 in the diffusion chamber group were involved in the inhibition of all pathogens. Bacterial cells were physically parted in the diffusion chamber group, while the diffusion of extracellular compounds and nutrients through the filter was probable. Whilst, contrasting the diffusion chamber group, bacterial cells could also interact with co-culture group pathogens. It might be stated that, the inhibitory effect of L. plantarum KLDS 1.0344 against the given foodborne pathogenic strains is due to the contact-dependent inhibition (CDI) mechanism.

\section{Discussion}

In the present study, L. plantarum KLDS 1.0344 (Tables 1 and 2) displayed a stronger antimicrobial activity against the two pathogens (Gram positive) i.e., S. aureus and L. monocytogenes. And likewise, exhibited antimicrobial potentiality against two Gram negative pathogenic strains, i.e., E. coli and S. typhimurium.

Employment of LAB has been of significant interest to constrain the pathogens (in vitro). Presently, numerous Lactococcus and Lactobacillus species have been assessed for their executability to impede the progression of Gram negative and Gram positive infectious agents in different prototypical 
organisms [46]. The bactericidal effect of protease sensitive bacteriocins of the LAB has been mostly shown to obstruct the activities of Gram negative pathogens $[47,48]$. Conversely, the hostility of LAB against Gram-negative pathogens are thought to be owing to the formation of hydrogen peroxide and organic acids [49].

LAB comprising numerous L. plantarum strains had been investigated to yield varied antimicrobial agents, for instance, hydrogen peroxide, organic acids, bacteriocins, diacetyl and antimicrobial peptides, owing to a versatile range of mechanisms $[17,50,51]$. Some LAB, like, L. plantarum, display adverse effect towards spoilage and pathogenic microbes. This antagonistic attitude has been frequently attributed to produce (organic) lactic and phenyl lactic acids [12-14,52]. On the other hand, the production of (bacteriocins or bacteriocin-like) compounds has been found to explicate the antimicrobial potency applied by lactobacilli $[15,16,53]$.

Numerous studies ascertained that LAB has the capability to yield antibacterial semantics counting, inhibitory enzymes, organic acids, diacetyl, bacteriocins, and hydrogen peroxide to constrain the growth of pathogenic strains up to a very wide range [54,55]. Loss of antibacterial activity of L. plantarum KLDS 1.0344 was found subsequently treating with pepsin, demonstrating that bacteriocin-identical compound was the peptide. After treating with protein digested enzymes like pronase, pepsin, bromelain, protease, ficin and $\alpha$-chymotrypsin. Decreasing antimicrobial activity unveiled that the bacteriocin was peptide in nature (Table 3). Bacteriocins are the heterogeneously diverse group of proteins and antibacterial peptides that differ in their mode of action, the spectrum of activity, genetic origin, molecular mass and biochemical properties [56]. Some other researchers investigated the bactericidal influence might be due to the organic acids alone or in a blend with bacteriocins peptides [57].

Han et al. (2017) [58] and Katina et al. (2002) [59] stated that all Lactobacillus species retain eminent acidifying activity owing to the production of lactic and acidic acids. Anas et al. (2008) [60] ascertained that, after $24 \mathrm{~h}$, the mixed culture of L. plantarum and Staphylococcus aureus produced a considerably excessive amount of lactic acid $\left(69.4^{\circ} \mathrm{D}\right)$.

After applying the proteases, it was perceived that the antibacterial agent of L. plantarum KLDS 1.0344 could be bacteriocin-like compound. Moreover, Pei et al. (2018) [61] investigated the antimicrobial potential of partly refined bacteriocins made by Lactobacillus sp. and displayed an impressive increase in antimicrobial effectiveness against B. cereus, S. aureus and E. coli (Figure 2). Bacteriocins have been demarcated as distinguished antimicrobial peptides/proteins, mainly directed to impede the growth of related species, detected in numerous genera of bacteria, including LAB [62].

Plantaricins are the bacteriocins manufactured by L. plantarum [63], while, Abo Amer, (2007) [64] witnessed the antimicrobial agent discharged by L. plantarum AA135 was greatly vigorous against a vast variety of Gram negative and Gram positive pathogens. Furthermore, Martine et al. (2013) [65], and Todorov et al. (2010) [66] reported that the bacteriocins like bacST216Ch and bacST202Ch, excreted by the L. plantarum strains sequestered from Chourico and Beloura, restrained the growth of certain meat putrefying Gram negative and positive bacteria. L. plantarum B0105 isolated from the conventionally fermented mustard of Taiwan, pragmatic to excrete bacteriocin that inhibited the Streptococcus mutans [67]. L. plantarum isolated from goat feta cheese exhibited bactericidal impact to resist Listeria monocytogenes [65].

Numerous lactococci and lactobacilli species are nominated to be inhibitory against $S$. aureus and E. coli in vivo and in vitro [36,60,68-74]. Lactic acid bacteria strains like Lactobacillus plantarum, Lactobacillus paracasei and four strains of Lactobacillus fermentum, not only, showed the better probiotic potential, but also, decreased the proliferation of enteropathogenic bacteria which were isolated from healthy infant feces, such as, Shigella flexneri Yersinia enterocolitica, Salmonella enteritidis and Shigella sonnei [75]. These Lactobacillus strains have been proved to be useful to treat diarrhea [76].

The complete disappearance of antibacterial properties of bacteriocin obtained from L. plantarum KLDS 1.0344 was detected against S. aureus, S. typhimurium, E. coli. and L. monocytogenes when $\mathrm{pH}$ was adjusted to 7 (Table 4). Lin et al. (2008) [57] also disclosed that the cultures of LAP5 cells neutralized to 
$7.0 \mathrm{pH}$, the alienating properties against Salmonella indicated non inhibitory potential. Alike findings testified that at $\mathrm{pH}$ 5.0, acidocin B produced by L. acidophilus retained $50 \%$ activity [77]. Main categories of LAB tailored bacteriocins consisted of lantibiotics, large heat-stable proteins and complex peptides, while heat stable property of bacteriocin compounds increased their applications [56,77]. In our present research work, the bacteriocin from L. plantarum KLDS 1.0344 has been found considerably heat and $\mathrm{pH}$ tolerant and potent bio preservative agent likewise. These potentials could make it useful natural food additive in food applications, which are at present, the matter of broad and extensive research. Searching the new bacteriocins encompassing a panoramic spectrum of antimicrobial activity are being investigated by some researchers.

Furthermore, results from Figure 4A-D) exhibited the viable count of four pathogens declined at 3.47 logs in the diffusion chamber group and 2.56 logs in co-culture group. These findings were analogous to the results of Atassi et al. (2006) [78] study, which disclosed that in viable cells of bacteria, the L. helveticus KS300 reduced pathogenic E. coli C1845, S. typhimurium SL1344 and IH11128 with a reduction of 2.0-5.5 logs. We should essentially emphasize that the unusual factors might be prospective for these outcomes and additional positive aspects could more decrease pathogenic progression. Former investigations on co-culture reticence provided an antimicrobial theory known as contact-dependent inhibition (CDI) mechanism [79-81]. In the present study it has been shown that the antimicrobial potential of the L. plantarum was associated with bacteria itself and bactericidal activity of the diffusion chamber group was compromising than the co-culture group. It is expected that, the antimicrobial action of bacteria itself could be correlated to the previously stated CDI mechanism. This mechanism could be illuminated by the interchange of information amongst the bacteria. Such ransfer of information encompassed, secretion systems, conjugation, allolysis, and nanotubes and contact-dependent inhibition [79].

Type IV and VI secretion pathways were ascertained in (Gram negative) bacteria. They assist the transportation of molecules, proteins or DNA straight into prokaryote cells from the bacterial cytoplasm. Conjugation is a straight allocation of genetic material amongst the microbial cells by a bridge-like connection or through smooth cell-to-cell contact [82]. Apart from these pathways, several researchers also verified that certain Escherichia coli strains might cause CDI of other E. coli strains $[81,83,84]$. CDI mechanism was identified among proteo-bacteria, but did not demonstrate experimentally in (Gram positive) bacteria [85].

According to Jabbari et al. (2017) [86], during co-cultivation with the pathogens and separate cultivation at $37 \pm 1^{\circ} \mathrm{C}$, L. plantarum kept the high concentration of viable cells. L. plantarum reduced the concentration of viable cells of E. coli ATCC 25922, Klebsiella pneumonia and Salmonella spp. The researcher has described thatthe inhibition of the growth of pathogens was attributable to generate other organic acids and lactic acid, which acidified the medium and altered the conditions for the growth of the pathogens.

\section{Materials and Methods}

\subsection{Bacterial Strains and Growth Conditions}

L. plantarum KLDS 1.0317, 1.0318, 1.0344, 1.0386, 1.0628, 1.0985, 1.0986 and other Lactobacilli utilized for antimicrobial spectrum were sequestrated from conventional cheese in Inner Mongolia and stored in Key Lab Dairy Science, Ministry of Education, China. 16S rDNA sequence analysis was used for the identification of these strains and these were anaerobically incubated in modified de Man, Rogosa, and Sharpe (mMRS) broth [87] at $37^{\circ} \mathrm{C}$. Four pathogenic strains, namely, Escherichia coli O157:H7 (ATCC 43889), Salmonella typhimurium (ATCC 14028), Listeria monocytogenes (ATCC 19115) and Staphylococcus aureus (ATCC 25923) were procured from entry-exit IQB (Inspection and Quarantine Bureau), Hubei province of China. These pathogenic strains were then aerobically incubated in BHI (Brain Heart Infusion broth, Qingdao Hope Biotechnology Co., Ltd. Shandong, China) at $37^{\circ} \mathrm{C}$ and were utilized as indicator bacteria for the antimicrobial assays. 


\subsection{Preparation Cell Free Supernatants of L. plantarum and Screening for Antimicrobial Potentiality}

$2 \mathrm{~mL}$ of L. plantarum cultures $\left(10^{8} \mathrm{CFUmL}^{-1}\right)$ were inoculated individually into mMRS broth $(100 \mathrm{~mL})$ and incubated for $24 \mathrm{~h}$ at $37^{\circ} \mathrm{C}$ (Intelligent Biochemical Incubator, SPX-150B, Yangzhou, China). Then centrifugation of the cultures was done for $10 \mathrm{~min}$ at $10,000 \times \mathrm{g}$ and $4{ }^{\circ} \mathrm{C}$ (Thermo Sorvall Legend Micro, 21 Microcentrifuge, ThermoFisher, Waltham, MA USA). Supernatants were then filter-sterilized through sterile filters $0.22 \mu \mathrm{m}$-pore-sized (Tianjin Navigator Lab instrument Co., Ltd. Tianjin, China) after discarding the bacteria precipitate.

The Oxford cup technique for the antimicrobial potentiality of L. plantarum KLDS strains against foodborne pathogens was explored in accordance to Wang et al. 2007:2009 [88,89] and Zhai et al. (2015) [90], with some adjustments. Initially, $12 \mathrm{~mL}$ of agar medium $(1.5 \% w / v)$ was poured into the plate and was solidified. Formerly, in the stationary phase, $1 \%$ of indicator strain was injected into $12 \mathrm{~mL}$ of apposite $\mathrm{BHI}$ agar $1.2 \%(w / v)$, at $45^{\circ} \mathrm{C}$. Then, the mixtures were moved onto agar media and permitted to harden. Then, three sterilized Oxford Cups were taken. These cups were placed and pressed slightly on BHI agar surface, to degas the interspace between agar surface and cups. Later on, $200 \mu \mathrm{L}$ of CFS and the same volume of culture dribbled into two cups, respectively. Then, as control, sterile water $(200 \mu \mathrm{L})$ delivered into the third cup. Plates were piled into incubator by providing aerobic conditions at $37^{\circ} \mathrm{C}$ for $24 \mathrm{~h}$ or $48 \mathrm{~h}$ and, antimicrobial activity was witnessed around the Oxford Cups, close to growth-free inhibition zones. Inhibition zones computed from the edges of cups in $\mathrm{mm}$. The current trial was performed in triplicate.

\subsection{Antibacterial Ambit of L. plantarum KLDS 1.0344}

The antibacterial ambit of L. plantarum KLDS 1.0344 was evaluated in comparison to eleven indicator strains enclosing Lactobacilli and foodborne pathogens by the use of Oxford Cups. Primarily, $12 \mathrm{~mL}$ of agar medium $(1.5 \%(w / v)$ was dispensed into the plate and uphold till solidified. In the stationary phase, $1 \%$ of indicator strain was injected into $12 \mathrm{~mL}$ of apposite agar medium $1.2 \%(w / v)$, at $45^{\circ} \mathrm{C}$. Formerly on agar medium the mix transferred and permitted to congeal. Then, three sterilized Oxford Cups were taken. These cups were placed and pressed slightly on BHI agar surface, to degas the interspace between agar surface and cups. Later on, $200 \mu \mathrm{L}$ of CFS and the same volume of culture dribbled into two cups, respectively. Then, as control, sterile water $(200 \mu \mathrm{L})$ delivered into the third cup. Plates were piled into incubator by providing aerobic conditions at $37^{\circ} \mathrm{C}$ for $24 \mathrm{~h}$ or $48 \mathrm{~h}$ and, antimicrobial activity was witnessed around the Oxford Cups, close to growth-free inhibition zones. Inhibition zones computed from the edges of cups in $\mathrm{mm}$. The current trial was performed in triplicate.

The plates were put in incubator providing aerobic conditions at $37^{\circ} \mathrm{C}$ for $24 \mathrm{~h}$ or $48 \mathrm{~h}$ and around the Oxford Cups. Inhibition zones computed from the edges of cups in $\mathrm{mm}$. The incumbent experiment conceded in triplicate.

\subsection{Quantification of Acid Production of L. plantarum KLDS 1.0344}

To determine the acid production capability of L. plantarum KLDS 1.0344 , a deduction of $10 \mathrm{~mL}$ of pure culture L. plantarum KLDS1.0344 and mixed culture with E. coli, L. monocytogenes, S. typhimurium and $S$. aureus was individually transferred in a $100 \mathrm{~mL}$ conical flask and 5 droplets of phenolphthalein indicator $\left(2 \mathrm{mg} / \mathrm{mL}\right.$ in ethanol $\left.60^{\circ}\right)$ were imparted. $\mathrm{NaOH} 1 / 9 \mathrm{~N}$ was used to neutralize acidity until the appearance of a persistent pink color. Titrating solution volume was deliberated to prefigure the production of acidity, assessed in dornic degree and a PHS-3C electrode $\mathrm{pH}$ meter (METTLER TOLEDO, Switzerland) was used to measure the $\mathrm{pH}$ of the culture after every $4 \mathrm{~h}$. Each experiment was replicated thrice [60].

\subsection{Mixed Culture Inhibition Assay}

Antimicrobial potentiality against E. coli, S. aureus, S. typhimurium and L. monocytogenes cells was performed by using a mixed culture method. Equal volumes of L. plantarum KLDS1.0344 (10 CFU 
per $\mathrm{mL}$ ) and $10^{3} \mathrm{CFU}$ per $\mathrm{mL}$ of each pathogen were co-cultured into a diffusion chamber which was split with a $0.22 \mu \mathrm{m}$ size of the filter in their respective cultivating medium as described by Saraoui et al. (2016) [79] and, incubation was executed at $37^{\circ} \mathrm{C}$ for $24 \mathrm{~h}$. $1 \%$ of both L. plantarum KLDS 1.0344 and pathogens $10^{6} \mathrm{CFU}$ per $\mathrm{mL}$ and $10^{3} \mathrm{CFU}$ per $\mathrm{mL}$, respectively were mono-cultured into mMRS and BHI broth used as a control medium. Every $4 \mathrm{~h}$, all the cultures were dispersed onto mMRS agar and BHI plates with proper dilutions, and $20 \mathrm{~h}$ incubation was done at $37^{\circ} \mathrm{C}$. Colonies of L. plantarum KLDS 1.0344 and pathogens were computed. PHS-3C electrode $\mathrm{pH}$ meter (METTLER TOLEDO, Switzerland) was used to measure the $\mathrm{pH}$ of above-mentioned cultures, after every $4 \mathrm{~h}$. Every experiment was replicated thrice.

\subsection{Antimicrobial Peptide Production}

$100 \mathrm{~mL}$ mMRS broth was inoculated with $2 \%$ L. plantarum KLDS $1.0344\left(10^{8} \mathrm{CFU}\right.$ per mL) and incubated at $37^{\circ} \mathrm{C}$ for $24 \mathrm{~h}$. Afterwards, culture centrifugation was performed at $10,000 \times g$ for $10 \mathrm{~min}$ at $4{ }^{\circ} \mathrm{C}$. All supernatants were then filter-sterilized using a sterile porous filter $(0.22 \mu \mathrm{m}) .1 \mathrm{~N} \mathrm{NaOH}$ was used to neutralize the resulting CFS to $\mathrm{pH} 6.5$ and catalase $(5 \mathrm{mg}$ per $\mathrm{mL}$ ) was used for the elimination of the hydrogen peroxide inhibitory effect. Finally, neutralized CFS (bacteriocin-like and bacteriocin metabolites) of the L. plantarum were tested against four pathogenic bacteria (L. monocytogenes, S. aureus, E. coli O157:H7 and S. typhimurium) to evaluate the antibacterial activity [91].

\subsection{Antimicrobial Fractional Refinement by Dialysis and Ammonium Sulfate Precipitation}

$20 \mathrm{~mL}$ of crude bacteriocin-like were taken and ammonium sulfate solution $(60 \%)$ was incrementally dispensed on the sample in a glass beaker. A magnetic stirrer (85-2 Hangzhou instrument motor Co., Ltd., Hangzhou, China) was used to stir the mixture for $2 \mathrm{~h}$. Centrifugation (at 10,000 rpm) of the solution was accomplished at $4{ }^{\circ} \mathrm{C}$, for $20 \mathrm{~min}$. The precipitate was re-suspended in $25 \mathrm{~mL}$ buffer of potassium phosphate (10 mM, pH 7.0), after discarding the supernatant. Dialysis membrane was cut into the desired length, softly squeezed and opened. A cutoff value of the dialysis membrane was less than $1200 \mathrm{Da}$. The membrane was closed by fastening with a thread from one end. Samples of bacteriocin-like peptides were decanted on the dialysis membrane and knotted on a glass rod. Then, it was retained half soaked in $(10 \mathrm{mM})$ phosphate buffer solution in a beaker and gently stirred for 12-18 $\mathrm{h}$ with a magnetic stirrer. To confirm appropriate dialysis of protein, the buffer was changed for every $3 \mathrm{~h}$ during the mixing procedure. Membrane bag was collected after dialysis completion, and stored at $4{ }^{\circ} \mathrm{C}$ carefully. Finally, the determination of the antibacterial activity of the dialyzed bacteriocin was performed by agar well diffusion procedure [91].

\subsubsection{The Sensitivity of Antimicrobial Substances from L. plantarum LKDS 1.0344 to} Proteolytic Enzymes

For the rectification of the antimicrobial elements of L. plantarum CFS were prepared by incubating $\mathrm{CFS}\left(1 \mathrm{~h}\right.$ at $\left.37^{\circ} \mathrm{C}\right)$ with protease, pepsin, bromelain, pronase, $\alpha$-chymotrypsin, and ficin. All enzymes were utilized in potassium phosphate buffer $(10 \mathrm{mmol}$ per $\mathrm{L}, \mathrm{pH}$ 7.0) with a concentration of $5 \mathrm{mg}$ per $\mathrm{mL}$. Controls were sustained by using CSF in buffer without having enzymes. Residual antimicrobial inhibition of S. aureus, E. coli, L. monocytogenes and, S. typhimurium was assessed with the use of Oxford Cups. All experiments were replicated thrice [11].

\subsubsection{Thermal Stability of Partially Purified Antimicrobial Compounds}

Incubation of partially purified bacteriocin containing samples was carried out at respective temperatures of $80^{\circ} \mathrm{C}, 100^{\circ} \mathrm{C}, 120^{\circ} \mathrm{C}$ and samples were taken at respective intervals of 20,30 and $40 \mathrm{~min}$. Samples were cooled to room temperature after heat treatment, and agar well diffusion test was done to assess the bactericidal of bacteriocin [92]. The Inhibition activity (\%) was calculated as in Equation (1). 


$$
\frac{\left[(\text { inhibition zone diameter })^{2}-(10 \mathrm{~mm})^{2}\right]}{\left[(\text { max. inhibition zone diameter })^{2}-(10 \mathrm{~mm})^{2}\right]} \times 100
$$

Inhibition zone diameter $=$ mean value of the diameter of the treated sample $(\mathrm{mm})$

Max. Inhibition zone diameter $=$ mean value of diameter for control $(\mathrm{mm})$

\subsection{3. pH Stability of Partially Purified Antimicrobial Compounds}

The $\mathrm{pH}$ stability of partially purified bacteriocin was tested by gradual $\mathrm{pH}$ adjustment from 2-8, in stages of one $\mathrm{pH}$ unit using $1 \mathrm{~N} \mathrm{NaOH}$ or $1 \mathrm{~N} \mathrm{HCl}$. The incubation of the samples was done for $1 \mathrm{~h}$ at $30^{\circ} \mathrm{C}$ and agar well diffusion technique was utilized to admeasure the bactericidal activity of the (partially refined) bacteriocin in triplicate against L. monocytogenes, E. coli, S. typhimurium and S. aureus were used as indicators. Inhibition activity (\%) was calculated by using Equation (1) [67].

\subsection{Electrophoresis Analysis}

The molecular weight of partially purified bacteriocin preparations was determined by SDS-PAGE (Sodium dodecyl sulfate-polyacrylamide gel electrophoresis). The $30 \mu \mathrm{L}$ sample was homogenized with $2 \%$ SDS and dithiothreitol (DTT) adding a little glycerin to increase the density and heating in boiling water for $5 \mathrm{~min}$ deal and then loaded onto gel, along with molecular weight marker mix like by using a Mini- Protean 4 cell system (Bio-Rad, Hercules, CA, USA), $100 \mathrm{~V}$ and $20 \mathrm{~mA}$ in the separation gel at $\mathrm{pH}$ 8.3. The gel was stained with $50 \mathrm{~mL}$ of $(0.1 \mathrm{M})$ Coomassie brilliant blue R-250 for $4 \mathrm{~h}$. The decolorizing solution was decolorized for $12 \mathrm{~h}$ until the electrophoresis band was clear. After the background was decolorized and cleaned, the gel imaging system was used for imaging and data acquisition [91].

\subsection{Statistical Analyses}

Entire analyses were completed in triplicate and the data was compiled. Tukey method was utilized by using the statistical program Statistics 8.1 (Analytical Software, SAS/STAT ${ }^{\circledR}$, Cary, NC, USA) for analysis of variance (ANOVA) and comparison of means. Statistically, the difference was pondered as significant when the $p<0.05$. Standard errors and mean values were deliberated and demonstrated in charts as coordinate pairs with error bars.

\section{Conclusions}

This study explored that the L. plantarum KLDS 1.0344 possesses a substantial antimicrobial capability against miscellaneous pathogenic bacterial strains, including both the Gram negative and Gram positive types in vitro. Acid production, as well as the biosynthesis of bacteriocin-like compounds is anticipated as one of the mechanisms through which the antimicrobial activity is wielded by L. plantarum KLDS1.0344. Bacteriocin-like compounds cultivated from L. plantarum KLDS1.0344 displayed vehement antibacterial competency against foodborne pathogens, $\mathrm{pH}$ and heat stability and, sensitivity to proteolytic enzymes. The outcome of the present study provides information about the antimicrobial potentials of the KLDS strains and this information could be helpful to select the probiotics, starters and natural antimicrobial agents against foodborne pathogens in meat-based processed or partially processed food products (Hams, salami, sausages), milk based fermented (cheeses, kefir, yoghurt, sour cream) and non-fermented products (infant formula powders, ice creams, desserts). As in this modern era the consumers are aware of the concepts of food safety, the consumption of healthy and safer food is getting prime importance, so, on the basis of results obtained from the current study, it might be anticipated that these discoveries will intensify the use of L. palntarum in the milk and meat-based food processing industries to produce safe, healthy and longer shelf life food products. 
Author Contributions: Z.M. has designed and carried out the present research work, conducted experiments, and has written the present manuscript. R.R. helped in analyzing the statistical data, elaborating, and drawing the figures. A.A. (Amro Abdelazez) provided help during the experimentation. M.A., A.A. (Adnan Amjad) and S.Z. also helped with technical issues, provided help in proofreading and presenting the work in its present form. S.Y. provided a place, lab facilities, and funding for the present research work.

Funding: The presented study was sponsored by “The Science and Technology Innovation Program of Hubei Province (Grant No. 2015ABA035)" and "The Technology Innovation Major Project of Hubei Province Grant No. 2018ABA072)".

Conflicts of Interest: All of the authors solemnly declare that, there is no conflict of interest in the present research work.

\section{References}

1. WHO. WHO Methods and Data Sources for Country-Level Causes of Death 2000-2015; WHO: Geneva, Switzerland, 2017.

2. The World Health Organization. Foodborne Disease Outbreaks: Guidelines for Investigation and Control WHO Library Cataloguing-in-Publication Data; WHO: Geneva, Switzerland, 2008.

3. Flint, J.A.; Van Duynhoven, Y.T.; Angulo, F.J.; DeLong, S.M.; Braun, P.; Kirk, M.; Scallan, E.; Fitzgerald, M.; Adak, G.K.; Sockett, P.; et al. Estimating the burden of acute gastroenteritis, foodborne disease, and pathogens commonly transmitted by food: An International Review. Clin. Infect. Dis. 2005, 41, 698-704. [CrossRef] [PubMed]

4. Anyogu, A.; Awamaria, B.; Sutherland, J.P.; Ouoba, L.I.I. Molecular characterisation and antimicrobial activity of bacteria associated with submerged lactic acid cassava fermentation. Food Control 2014, 39, 119-127. [CrossRef]

5. da Silva Sabo, S.; Vitolo, M.; González, J.M.D.; de Souza Oliveira, R.P. Overview of Lactobacillus plantarum as a promising bacteriocin producer among lactic acid bacteria. Food Res. Int. 2014, 64, 527-536. [CrossRef] [PubMed]

6. Šušković, J.; Kos, B.; Beganović, J.; Pavunc, A.L.; Habjanič, K.; Matoć, S. Antimicrobial activity - The most important property of probiotic and starter lactic acid bacteria. Food Technol. Biotechnol. 2010, 48, $296-307$.

7. Guidone, A.; Zotta, T.; Ross, R.P.; Stanton, C.; Rea, M.C.; Parente, E.; Ricciardi, A. Functional properties of Lactobacillus plantarum strains: A multivariate screening study. LWT Food Sci. Technol. 2014, 56, 69-76. [CrossRef]

8. Gaur, Y.; Narayan, K.; Chauhan, S.; Ali, A. Bacteriocinogeny: Concept, nomenclature, prevalence and application. Indian J. Microbiol. 2004, 44, 1-30.

9. Jia, F.; Zhang, L.; Pang, X.; Gu, X.; Abdelazez, A.; Liang, Y. Genomics Complete genome sequence of bacteriocin-producing Lactobacillus plantarum KLDS1. 0391, a probiotic strain with gastrointestinal tract resistance and adhesion to the intestinal epithelial cells. Genomics 2017, 109, 6-11. [CrossRef]

10. Kalita, D.; Saikia, S.; Gautam, G.; Mukhopadhyay, R. LWT - Food Science and Technology Characteristics of synbiotic spray dried powder of litchi juice with Lactobacillus plantarum and different carrier materials. LWT Food Sci. Technol. 2018, 87, 351-360. [CrossRef]

11. Oguntoyinbo, F.A.; Narbad, A. Multifunctional properties of Lactobacillus plantarum strains isolated from fermented cereal foods. J. Funct. Foods 2015, 17, 621-631. [CrossRef]

12. Rodríguez-Pazo, N.; Vázquez-Araújo, L.; Pérez-Rodríguez, N.; Cortés-Diéguez, S.; Domínguez, J.M. Cell-free supernatants obtained from fermentation of cheese whey hydrolyzates and phenylpyruvic acid by Lactobacillus plantarum as a source of antimicrobial compounds, bacteriocins, and natural aromas. Appl. Biochem. Biotechnol. 2013, 171, 1042-1060. [CrossRef]

13. Tejero-Sariñena, S.; Barlow, J.; Costabile, A.; Gibson, G.R.; Rowland, I. In vitro evaluation of the antimicrobial activity of a range of probiotics against pathogens: Evidence for the effects of organic acids. Anaerobe 2012, 18, 530-538. [CrossRef] [PubMed]

14. Neal-McKinney, J.M.; Lu, X.; Duong, T.; Larson, C.L.; Call, D.R.; Shah, D.H.; Konkel, M.E. Production of organic acids by probiotic Lactobacilli can be used to reduce pathogen load in poultry. PLoS ONE 2012, 7, e43928. [CrossRef] [PubMed] 
15. Al Kassaa, I.; Hamze, M.; Hober, D.; Chihib, N.E.; Drider, D. Identification of vaginal lactobacilli with potential probiotic properties isolated from women in North Lebanon. Microb. Ecol. 2014, 67, 722-734. [CrossRef] [PubMed]

16. Kos, B.; Beganović, J.; Jurašić, L.; Švađumović, M. Coculture-inducible bacteriocin biosynthesis of different probiotic strains by dairy starter culture Lactococcus lactis. Mljekarstvo 2011, 61, 273-282.

17. Cortés-Zavaleta, O.; López-Malo, A.; Hernández-Mendoza, A.; García, H.S. Antifungal activity of lactobacilli and its relationship with 3-phenyllactic acid production. Int. J. Food Microbiol. 2014, 173, 30-35. [CrossRef] [PubMed]

18. Reis, J.A.; Paula, A.T.; Casarotti, S.N.; Penna, A.L.B. Lactic acid bacteria antimicrobial compounds: Characteristics and applications. Food Eng. Rev. 2012, 4, 124-140. [CrossRef]

19. Varsha, K.K.; Nampoothiri, K.M. Appraisal of lactic acid bacteria as protective cultures. Food Control 2016, 69, 61-64. [CrossRef]

20. Ma, Q.; Fu, Y.; Sun, H.; Huang, Y.; Li, L.; Yu, Q.; Dinnyes, A.; Sun, Q. Antimicrobial resistance of Lactobacillus spp. from fermented foods and human gut. LWT Food Sci. Technol. 2017, 86, 201-208. [CrossRef]

21. Demirbaş, F.; İspirli, H.; Kurnaz, A.A.; Yilmaz, M.T.; Dertli, E. Antimicrobial and functional properties of lactic acid bacteria isolated from sourdoughs. LWT Food Sci. Technol. 2017, 79, 361-366. [CrossRef]

22. Elviso, S.B.; Iordano, M.G.; Olci, P.D.; Eppa, G.Z. Original article in vitro cholesterol-lowering activity of Lactobacillus plantarum and Lactobacillus paracasei strains isolated from the Italian Castelmagno PDO cheese. Dairy Sci. Technol. 2009, 89, 169-176. [CrossRef]

23. Sip, A.; Wieckowicz, M.; Olejnik-Schmidt, A.; Grajek, W. Anti-Listeria activity of lactic acid bacteria isolated from golka, a regional cheese produced in Poland. Food Control 2012, 26, 117-124. [CrossRef]

24. Papanikolaou, Z.; Hatzikamari, M.; Georgakopoulos, P.; Yiangou, M.; Litopoulou-tzanetaki, E.; Tzanetakis, N. Selection of dominant NSLAB from a mature traditional cheese according to their technological properties and in vitro intestinal challenges. J. Food Sci. 2012, 77, M298-M306. [CrossRef] [PubMed]

25. Turgut, T.; Erdoğan, A. Karın Kaymağı Peynirinden İzole Edilen Laktobasillerin Tanımlanması Makale Kodu (Article Code): KVFD-2011-5272 Identification of Lactobacilli Isolated from Cheese Karın Kaymak. Kafkas Üniversitesi Veteriner Fakültesi Dergisi 2012, 18, 209-213.

26. Veljovic, K.; Vukasinovic, M.; Strahinic, I.; Begovic, J.; Lozo, J.; Ostojic, M. Preliminary characterization of lactic acid bacteria isolated from Zlatar cheese. J. Appl. Microbiol. 2007, 103, 2142-2152. [CrossRef] [PubMed]

27. Nanda, D.K.; Tomar, S.K.; Singh, R.; Mal, G.; Singh, P.; Arora, D.K.; Joshi, B.K.; Chaudhary, R.; Kumar, D. Phenotypic and genotypic characterisation of Lactobacilli isolated from camel cheese produced in India. Int. J. Dairy Technol. 2011, 64, 437-443. [CrossRef]

28. Maris, S.; Meira, M.; Helfer, V.E.; Velho, R.V.; Lopes, F.C.; Brandelli, A. Probiotic potential of Lactobacillus spp. isolated from Brazilian regional ovine cheese. J. Dairy Res. 2012, 79, 119-127.

29. Duan, Y.; Tan, Z.; Wang, Y.; Li, Z.; Li, Z.; Qin, G.; Huo, Y.; Cai, Y. Identification and characterization of lactic acid bacteria isolated from Tibetan Qula cheese. J. Gen. Appl. Microbiol. 2008, 60, 51-60. [CrossRef]

30. Adegoke, G.O. Bacteriocin and cellulose production by lactic acid bacteria isolated from West African soft cheese. Afr. J. Biotechnol. 2007, 6, 2616-2619.

31. Zhang, J.; Zhang, X.; Zhang, L.; Zhao, Y.; Niu, C.; Yang, Z.; Li, S. Potential probiotic characterization of Lactobacillus plantarum strains isolated from Inner Mongolia "Hurood" Cheese. J. Microbiol. Biotechnol. 2014, 24, 225-235. [CrossRef]

32. Behera, S.S.; Ray, R.C.; Zdolec, N. Lactobacillus plantarum with functional properties: An approach to increase safety and shelf-life of fermented foods. BioMed Res. Int. 2018, 2018, 9361614. [CrossRef]

33. Kirk, M.D.; Pires, S.M.; Black, R.E.; Caipo, M.; Crump, J.A.; Devleesschauwer, B.; Döpfer, D.; Fazil, A.; Fischer-Walker, C.L.; Hald, T.; et al. Correction: World Health Organization estimates of the global and regional disease burden of 22 foodborne bacterial, protozoal, and viral diseases, 2010: A data synthesis. PLoS Med. 2015, 12, e1001921. [CrossRef] [PubMed]

34. Xiao, L.; Zhang, Z.; Sun, X.; Pan, Y.; Zhao, Y. Development of a quantitative real-time PCR assay for viable Salmonella spp. without enrichment. Food Control 2015, 57, 185-189. [CrossRef]

35. Omiccioli, E.; Amagliani, G.; Brandi, G.; Magnani, M. A new platform for Real-Time PCR detection of Salmonella spp., Listeria monocytogenes and Escherichia coli O157 in milk. Food Microbiol. 2009, 26, 615-622. [CrossRef] [PubMed] 
36. Liu, H.; Gao, Y.; Yu, L.R.; Jones, R.C.; Elkins, C.A.; Hart, M.E. Inhibition of Staphylococcus aureus by lysostaphin-expressing Lactobacillus plantarum WCFS1 in a modified genital tract secretion medium. Appl. Environ. Microbiol. 2011, 77, 8500-8508. [CrossRef] [PubMed]

37. Kase, J.A.; Zhang, G.; Chen, Y. Recent foodborne outbreaks in the United States linked to atypical vehicles-Lessons learned. Curr. Opin. Food Sci. 2017, 18, 56-63. [CrossRef]

38. Ly, V.; Parreira, V.R.; Farber, J.M. Current understanding and perspectives on Listeria monocytogenesin low-moisture foods. Curr. Opin. Food Sci. 2019, 26, 18-24. [CrossRef]

39. Thakur, M.; Asrani, R.K.; Patial, V. Listeria monocytogenes: A food-borne pathogen. In Foodborne Diseases; Elsevier: Amsterdam, The Netherlands, 2018; ISBN 9780128114964.

40. Kim, Y.C.; Won, H.K.; Lee, J.W.; Sohn, K.H.; Kim, M.H.; Kim, T.B.; Chang, Y.S.; Lee, B.J.; Cho, S.H.; Bachert, C.; et al. Staphylococcus aureus nasal colonization and asthma in adults: Systematic review and meta-analysis. J. Allergy Clin. Immunol. Pract. 2019, 7, 606-615. [CrossRef]

41. Oestergaard, L.B.; Schmiegelow, M.D.S.; Bruun, N.E.; Skov, R.; Andersen, P.S.; Larsen, A.R.; Gerds, T.A.; Dahl, A.; Petersen, A.; Lauridsen, T.K.; et al. Staphylococcus aureus bacteremia in children aged 5-18 years-Risk factors in the new Millennium. J. Pediatr. 2018, 203, 108-115. [CrossRef]

42. Tanveer, F.; Bhargava, A.; Riederer, K.; Johnson, L.B.; Khatib, R. Low frequency of Staphylococcus aureus in lower extremity skin and soft tissue infections. Am. J. Med. Sci. 2018, 356, 528-530. [CrossRef]

43. Wakabayashi, Y.; Umeda, K.; Yonogi, S.; Nakamura, H.; Yamamoto, K.; Kumeda, Y.; Kawatsu, K. Staphylococcal food poisoning caused by Staphylococcus argenteus harboring staphylococcal enterotoxin genes. Int. J. Food Microbiol. 2018, 265, 23-29. [CrossRef]

44. Beutin, L.; Martin, A. Outbreak of Shiga Toxin-Producing Escherichia coli (STEC) O104:H4 Infection in germany causes a paradigm shift with regard to human pathogenicity of STEC Sstrains. J. Food Prot. 2012, 75, 408-418. [CrossRef] [PubMed]

45. Gutiérrez-Larraínzar, M.; Rúa, J.; Caro, I.; de Castro, C.; de Arriaga, D.; García-Armesto, M.R.; del Valle, P. Evaluation of antimicrobial and antioxidant activities of natural phenolic compounds against foodborne pathogens and spoilage bacteria. Food Control 2012, 26, 555-563. [CrossRef]

46. Cálix-Lara, T.F.; Rajendran, M.; Talcott, S.T.; Smith, S.B.; Miller, R.K.; Castillo, A.; Sturino, J.M.; Taylor, T.M. Inhibition of Escherichia coli O157: H7 and Salmonella enterica on spinach and identification of antimicrobial substances produced by a commercial lactic acid bacteria food safety intervention. Food Microbiol. 2014, 38, 192-200. [CrossRef] [PubMed]

47. Son, S.H.; Jeon, H.L.; Yang, S.J.; Lee, N.K.; Paik, H.D. In vitro characterization of Lactobacillus brevis KU15006, an isolate from kimchi, reveals anti-adhesion activity against foodborne pathogens and antidiabetic properties. Microb. Pathog. 2017, 112, 135-141. [CrossRef] [PubMed]

48. Ito, A.; Sato, Y.; Kudo, S.; Sato, S.; Nakajima, H.; Toba, T. The screening of hydrogen peroxide-producing lactic acid bacteria and their application to inactivating psychrotrophic food-borne pathogens. Curr. Microbiol. 2003, 47, 231-236.

49. Chiu, H.H.; Tsai, C.C.; Hsih, H.Y.; Tsen, H.Y. Screening from pickled vegetables the potential probiotic strains of lactic acid bacteria able to inhibit the Salmonella invasion in mice. J. Appl. Microbiol. 2008, 104, 605-612. [CrossRef] [PubMed]

50. Tharmaraj, N.; Shah, N.P. Antimicrobial effects of probiotics against selected pathogenic and spoilage bacteria in cheese-based dips. Int. Food Res. J. 2009, 16, 261-276.

51. Herreros, M.A.; Sandoval, H.; González, L.; Castro, J.M.; Fresno, J.M.; Tornadijo, M.E. Antimicrobial activity and antibiotic resistance of lactic acid bacteria isolated from Armada cheese (a Spanish goats' milk cheese). Food Microbiol. 2005, 22, 455-459. [CrossRef]

52. Angmo, K.; Kumari, A.; Savitri; Bhalla, T.C. Probiotic characterization of lactic acid bacteria isolated from fermented foods and beverage of Ladakh. LWT Food Sci. Technol. 2016, 66, 428-435. [CrossRef]

53. Abushelaibi, A.; Al-Mahadin, S.; El-Tarabily, K.; Shah, N.P.; Ayyash, M. Characterization of potential probiotic lactic acid bacteria isolated from camel milk. LWT Food Sci. Technol. 2017, 79, 316-325. [CrossRef]

54. García-Ruiz, A.; Requena, T.; Peláez, C.; Bartolomé, B.; Moreno-Arribas, M.V.; Martínez-Cuesta, M.C. Antimicrobial activity of lacticin 3147 against oenological lactic acid bacteria. Combined effect with other antimicrobial agents. Food Control 2013, 32, 477-483. [CrossRef] 
55. Hernández, D.; Cardell, E.; Zárate, V. Antimicrobial activity of lactic acid bacteria isolated from Tenerife cheese: Initial characterization of plantaricin TF711, a bacteriocin-like substance produced by Lactobacillus plantarum TF711. J. Appl. Microbiol. 2005, 99, 77-84. [CrossRef] [PubMed]

56. Rojo-Bezares, B.; Sáenz, Y.; Navarro, L.; Zarazaga, M.; Ruiz-Larrea, F.; Torres, C. Coculture-inducible bacteriocin activity of Lactobacillus plantarum strain J23 isolated from grape must. Food Microbiol. 2007, 24, 482-491. [CrossRef] [PubMed]

57. Lin, C.K.; Tsai, H.C.; Lin, P.P.; Tsen, H.Y.; Tsai, C.C. Lactobacillus acidophilus LAP5 able to inhibit the Salmonella choleraesuis invasion to the human Caco-2 epithelial cell. Anaerobe 2008, 14, 251-255. [CrossRef] [PubMed]

58. Han, Q.; Kong, B.; Chen, Q.; Sun, F.; Zhang, H. In vitro comparison of probiotic properties of lactic acid bacteria isolated from Harbin dry sausages and selected probiotics. J. Funct. Foods 2017, 32, 391-400. [CrossRef]

59. Katina, K.; Sauri, M.; Alakomi, H.-L.; Mattila-Sandholm, T. Potential of lactic acid bacteria to inhibit rope spoilage in wheat sourdough bread. LWT Food Sci. Technol. 2002, 35, 38-45. [CrossRef]

60. Anas, M.; Jamal Eddine, H.; Mebrouk, K. Antimicrobial activity of Lactobacillus species isolated from Algerian raw goat's milk against Staphylococcus aureus. World J. Dairy Food Sci. 2008, 3, 39-49.

61. Pei, J.; Li, X.; Han, H.; Tao, Y. Purification and characterization of plantaricin SLG1, a novel bacteriocin produced by Lb. plantarum isolated from yak cheese. Food Control 2018, 84, 111-117. [CrossRef]

62. Yi, L.; Dang, J.; Zhang, L.; Wu, Y.; Liu, B.; Lü, X. Purification, characterization and bactericidal mechanism of a broad spectrum bacteriocin with antimicrobial activity against multidrug-resistant strains produced by Lactobacillus coryniformis XN8. Food Control 2016, 67, 53-62. [CrossRef]

63. Ben Omar, N.; Abriouel, H.; Keleke, S.; Sánchez Valenzuela, A.; Martínez-Cañamero, M.; Lucas López, R.; Ortega, E.; Gálvez, A. Bacteriocin-producing Lactobacillus strains isolated from poto poto, a Congolese fermented maize product, and genetic fingerprinting of their plantaricin operons. Int. J. Food Microbiol. 2008, 127, 18-25. [CrossRef]

64. Abo-Amer, A.E. Characterization of a bacteriocin-like inhibitory substance produced by Lactobacillus plantarum isolated from Egyptian home-made yogurt. ScienceAsia 2007, 33, 313-319. [CrossRef]

65. Martinez, R.C.R.; Wachsman, M.; Torres, N.I.; LeBlanc, J.G.; Todorov, S.D.; de Melo Franco, B.D.G. Biochemical, antimicrobial and molecular characterization of a noncytotoxic bacteriocin produced by Lactobacillus plantarum ST71KS. Food Microbiol. 2013, 34, 376-381. [CrossRef] [PubMed]

66. Todorov, S.D.; Ho, P.; Vaz-Velho, M.; Dicks, L.M.T. Characterization of bacteriocins produced by two strains of Lactobacillus plantarum isolated from Beloura and Chouriço, traditional pork products from Portugal. Meat Sci. 2010, 84, 334-343. [CrossRef] [PubMed]

67. Chun, C.C.; Chen, K.C.; Pin Der, D.; Peng, S.W.; Shu, C.W. Antibacterial properties of Lactobacillus plantarum isolated from fermented mustards against Streptococcus mutans. Afr. J. Microbiol. Res. 2013, 7, 4787-4793. [CrossRef]

68. Huang, R.; Tao, X.; Wan, C.; Li, S.; Xu, H.; Xu, F.; Shah, N.P.; Wei, H. In vitro probiotic characteristics of Lactobacillus plantarum ZDY 2013 and its modulatory effect on gut microbiota of mice. J. Dairy Sci. 2015, 98, 5850-5861. [CrossRef] [PubMed]

69. Kumar, A.; Kumar, D. Characterization of Lactobacillus isolated from dairy samples for probiotic properties. Anaerobe 2015, 33, 117-123. [CrossRef] [PubMed]

70. Savino, F.; Cordisco, L.; Tarasco, V.; Locatelli, E.; Di Gioia, D.; Oggero, R.; Matteuzzi, D. Antagonistic effect of Lactobacillus strains against gas-producing coliforms isolated from colicky infants. BMC Microbiol. 2011, 11, 157. [CrossRef] [PubMed]

71. Varma, P.; Dinesh, K.R.; Menon, K.K.; Biswas, R. Lactobacillus fermentum Iisolated from human colonic mucosal biopsyinhibits the growth and adhesion of enteric and foodborne pathogens. J. Food Sci. 2010, 75, M546-M551. [CrossRef]

72. Delbes-Paus, C.; Dorchies, G.; Chaabna, Z.; Callon, C.; Montel, M.C. Contribution of hydrogen peroxide to the inhibition of Staphylococcus aureus by Lactococcus garvieae in interaction with raw milk microbial community. Food Microbiol. 2010, 27, 924-932. [CrossRef]

73. Turner, M.S.; Lo, R.; Giffard, P.M. Inhibition of Staphylococcus aureus growth on tellurite-containing media by Lactobacillus reuteri is dependent on CyuC and thiol production. Appl. Environ. Microbiol. 2007, 73, 1005-1009. [CrossRef] 
74. Laughton, J.M.; Devillard, E.; Heinrichs, D.E.; Reid, G.; McCormick, J.K. Inhibition of expression of a Staphylococcal superantigen-like protein by a soluble factor from Lactobacillus reuteri. Microbiology 2006, 152, 1155-1167. [CrossRef] [PubMed]

75. Davoodabadi, A.; Soltan Dallal, M.M.; Rahimi Foroushani, A.; Douraghi, M.; Sharifi Yazdi, M.K.; Amin Harati, F. Antibacterial activity of Lactobacillus spp. isolated from the feces of healthy infants against enteropathogenic bacteria. Anaerobe 2015, 34, 53-58. [CrossRef] [PubMed]

76. Davoodabadi, A.; Dallal, M.M.S.; Lashani, E.; Ebrahimi, M.T. Antimicrobial activity of Lactobacillus spp. isolated from fecal flora of healthy breast-fed infants against diarrheagenic Escherichia coli. Jundishapur J. Microbiol. 2015, 8, e27852. [CrossRef] [PubMed]

77. Han, K.S.; Kim, Y.; Kim, S.H.; Oh, S. Characterization and purification of acidocin 1B, a bacteriocin produced by Lactobacillus acidophilus GP1B. J. Microbiol. Biotechnol. 2007, 17, 774-783. [PubMed]

78. Atassi, F.; Brassart, D.; Grob, P.; Graf, F.; Servin, A.L. In vitro antibacterial activity of Lactobacillus helveticus strain KS300 against diarrhoeagenic, uropathogenic and vaginosis-associated bacteria. J. Appl. Microbiol. 2006, 101, 647-654. [CrossRef] [PubMed]

79. Saraoui, T.; Fall, P.A.; Leroi, F.; Antignac, J.P.; Chéreau, S.; Pilet, M.F. Inhibition mechanism of Listeria monocytogenes by a bioprotective bacteria Lactococcus piscium CNCM I-4031. Food Microbiol. 2016, 53, 70-78. [CrossRef] [PubMed]

80. Bavananthasivam, J.; Dassanayake, R.P.; Kugadas, A.; Shanthalingam, S.; Call, D.R.; Knowles, D.P.; Srikumaran, S. Proximity-dependent inhibition of growth of Mannheimia haemolytica by Pasteurella multocida. Appl. Environ. Microbiol. 2012, 78, 6683-6688. [CrossRef]

81. Aoki, S.K.; Pamma, R.; Hernday, A.D.; Bickham, J.E.; Braaten, B.A.; Low, D. A contact-dependent inhibition of growth in Escherichia coli. Science 2005, 309, 1245-1248. [CrossRef]

82. Zechner, E.L.; Lang, S.; Schildbach, J.F. Assembly and mechanisms of bacterial type IV secretion machines. Philos. Trans. R. Soc. Lond. B. Biol. Sci. 2012, 367, 1073-1087. [CrossRef]

83. Schmidt, A.; Kochanowski, K.; Vedelaar, S.; Ahrné, E.; Volkmer, B.; Callipo, L.; Knoops, K.; Bauer, M.; Aebersold, R.; Heinemann, M. The quantitative and condition-dependent Escherichia coli proteome. Nat. Biotechnol. 2016, 34, 104-110. [CrossRef]

84. Sutrina, S.L.; Daniel, K.; Lewis, M.; Charles, N.T.; Anselm, C.K.E.; Thomas, N.; Holder, N. Biofilm growth of Escherichia coli is subject to cAMP-dependent and cAMPindependent inhibition. J. Mol. Microbiol. Biotechnol. 2015, 25, 209-225. [CrossRef] [PubMed]

85. Diner, E.J.; Beck, C.M.; Webb, J.S.; Low, D.A.; Hayes, C.S. Identification of a target cell permissive factor required for contact-dependent growth inhibition (CDI). Genes Dev. 2012, 26, 515-525. [CrossRef]

86. Jabbari, V.; Khiabani, M.S.; Mokarram, R.R.; Hassanzadeh, A.M.; Ahmadi, E.; Gharenaghadeh, S.; Karimi, N.; Kafil, H.S. Lactobacillus plantarum as a probiotic potential from Kouzeh cheese (Traditional Iranian Cheese) and its antimicrobial activity. Probiotics Antimicrob. Proteins 2017, 9, 189-193. [CrossRef]

87. Bian, X.; Evivie, S.E.; Muhammad, Z.; Luo, G.-W.; Liang, H.-Z.; Wang, N.-N.; Huo, G.-C. In vitro assessment of the antimicrobial potentials of Lactobacillus helveticus strains isolated from traditional cheese in Sinkiang China against food-borne pathogens. Food Funct. 2016, 7, 789-797. [CrossRef] [PubMed]

88. Wang, X.; Chi, Z.; Yue, L.; Li, J. Purification and characterization of killer toxin from a marine yeast Pichia anomala YF07b against the pathogenic yeast in crab. Curr. Microbiol. 2007, 55, 396-401. [CrossRef] [PubMed]

89. Wang, Y.; Lu, Z.; Wu, H.; Lv, F. Study on the antibiotic activity of microcapsule curcumin against foodborne pathogens. Int. J. Food Microbiol. 2009, 136, 71-74. [CrossRef] [PubMed]

90. Zhai, Q.; Yin, R.; Yu, L.; Wang, G.; Tian, F.; Yu, R.; Zhao, J.; Liu, X.; Chen, Y.Q.; Zhang, H.; et al. Screening of lactic acid bacteria with potential protective effects against cadmium toxicity. Food Control 2015, 54, 23-30. [CrossRef]

91. Srinivasan, P.; Khan, K.A.; Perumal, U.R.; Kumar, R.V.; Suganya, K.; Rajalakshmi, M. In vitro antibacterial activity of Lactobacillus plantarum isolated from soy milk. Int. J. Pharma Bio Sci. 2012, 3, $209-219$.

92. Gao, Y.; Jia, S.; Gao, Q.; Tan, Z. A novel bacteriocin with a broad inhibitory spectrum produced by Lactobacillus sake C2, isolated from traditional Chinese fermented cabbage. Food Control 2010, 21, 76-81. [CrossRef]

(C) 2019 by the authors. Licensee MDPI, Basel, Switzerland. This article is an open access article distributed under the terms and conditions of the Creative Commons Attribution (CC BY) license (http://creativecommons.org/licenses/by/4.0/). 